Prepared in cooperation with the

New Hampshire Department of Environmental Services

Geochemical, Isotopic, and Dissolved Gas Characteristics of Groundwater in a Fractured Crystalline-Rock Aquifer, Savage Municipal Well Superfund Site, Milford, New Hampshire, 2011

Open-File Report 2013-1089 
THIS PAGE INTENTIONALLY LEFT BLANK 


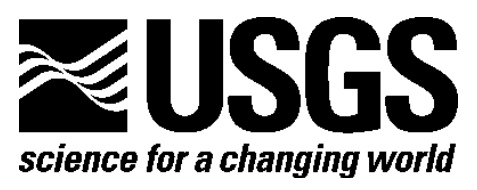

Prepared in cooperation with the

New Hampshire Department of Environmental Services

\section{Geochemical, Isotopic, and Dissolved Gas Characteristics of Groundwater in a Fractured Crystalline-Rock Aquifer, Savage Municipal Well Superfund Site, Milford, New Hampshire, 2011}

By Philip T. Harte

Open-File Report 2013-1089

U.S. Department of the Interior U.S. Geological Survey 


\section{U.S. Department of the Interior \\ SALLY JEWELL, Secretary}

\section{U.S. Geological Survey \\ Suzette M. Kimball, Acting Director}

U.S. Geological Survey, Reston, Virginia: 2013

For more information on the USGS-the Federal source for science about the Earth, its natural and living resources, natural hazards, and the environment-visit http://www.usgs.gov or call 1-888-ASK-USGS

For an overview of USGS information products, including maps, imagery, and publications, visit $h$ ttp://www.usgs.gov/pubprod

To order this and other USGS information products, visit http://store.usgs.gov

Suggested citation:

Harte, P.T., 2013, Geochemical, isotopic, and dissolved gas characteristics of groundwater in a fractured crystalline-rock aquifer, Savage Municipal Well Superfund site, Milford, New Hampshire, 2011: U.S. Geological Survey Open-File Report 2013-1089, 25 p., http://pubs.usgs.gov/of/2013/1089/.

Any use of trade, product, or firm names is for descriptive purposes only and does not imply endorsement by the U.S. Government.

Although this report is in the public domain, permission must be secured from the individual copyright owners to reproduce any copyrighted material contained within this report. 


\section{Acknowledgments}

This study was conducted as part of the remedial effort at the Savage Municipal Well Superfund site, specifically operable unit 3 (OU3), and is a collaborative effort between Federal, State, and local governments, and private companies and individuals. The author wishes to thank Robin Mongeon, project manager for the New Hampshire Department of Environmental Services (NHDES); and Richard Hull, site remedial project manager for the U.S. Environmental Protection Agency (USEPA), region 1, for their leadership in managing remedial efforts and their support. Thanks to Sharon Perkins also of the NHDES for assistance in planning and sampling of residential wells. Thanks also to personnel at Roy F. Weston, Inc., for much-needed logistical assistance and sampling of monitoring wells. 


\section{Contents}

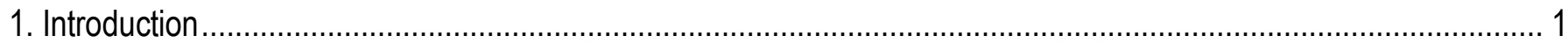

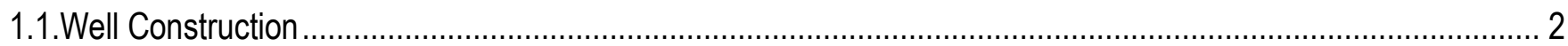

1.2.Geology, Fracture Characteristics, and Lineaments .......................................................................... 2

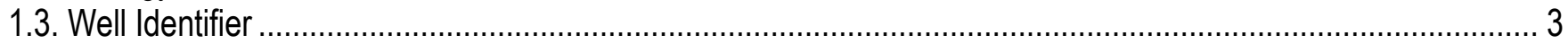

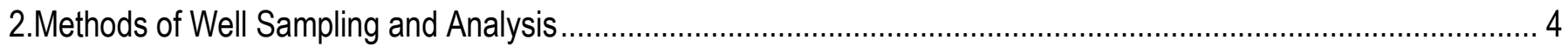

3.Results of Geochemistry, Isotopes, and Dissolved Gases in Groundwater ........................................................ 5

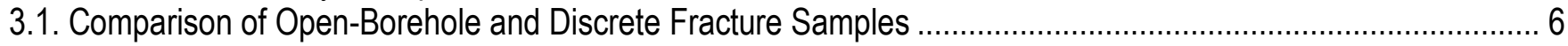

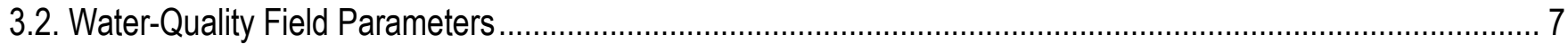

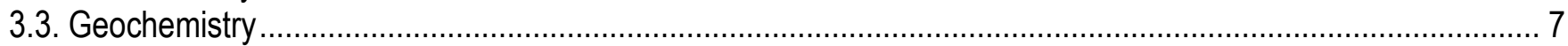

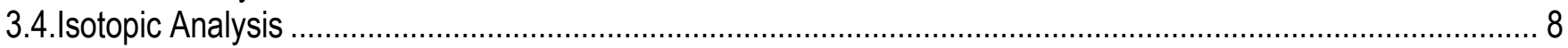

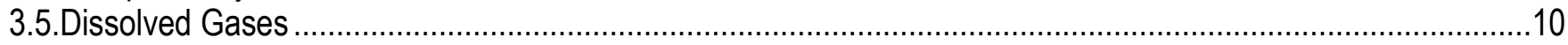

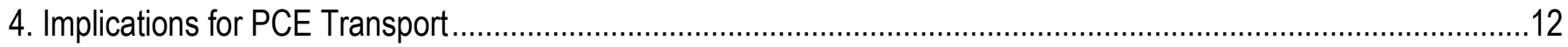

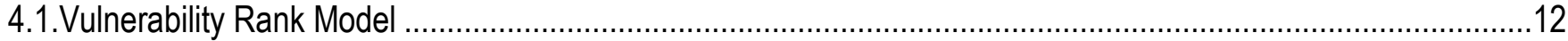

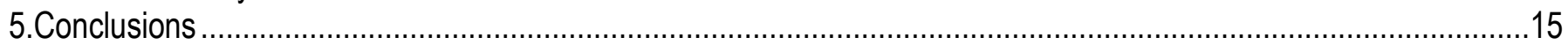

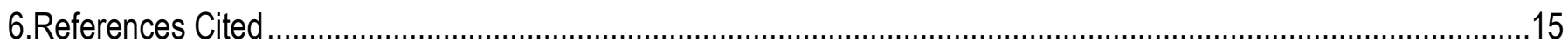

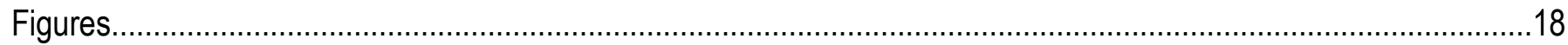

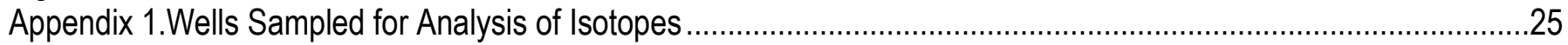

\section{Figures}

1. Location map of monitoring wells and residential-supply wells, Savage Municipal Well Superfund site, Milford, New Hampshire.

2. Piper diagram of major water type for residential and monitoring wells, Savage Municipal Well Superfund site, Milford, New Hampshire

3. Modified piper of major water type for residential and monitoring wells, classified by well parameter, Savage Municipal Well Superfund site, Milford, New Hampshire

4. Graphs showing relation of stable isotopes of $\delta D$ and $\delta^{18} \mathrm{O}$ of groundwater from residential and monitoring well samples and the local meteoric water line by $A$, well type and $B$, yield at Savage Superfund site, Milford, New Hampshire

5. Graph showing relation of $\delta^{13} \mathrm{C}$ and alkalinity of groundwater from residential and monitoring well samples, Savage Municipal Well Superfund site, Milford, New Hampshire.....

6. Graphs showing relation of recharge temperature from argon-nitrogen gas and $\delta^{13} \mathrm{C}$ of groundwater from residential and monitoring well samples for $A$, all wells and $B$, selected wells at the Savage Municipal Well Superfund site, Milford, New Hampshire 


\section{Tables}

1. Well construction for sampled wells, OU-3 Savage Superfund site, Milford, New Hampshire.

2. Chemical constituents, reporting limits and regulatory standards, OU-3 Savage Superfund site,

Milford, New Hampshire .....

3. Results of open-borehole and fracture specific samples for water-quality parameters from monitoring wells, Savage Superfund Site, Milford, New Hampshire....

4. Results of open-borehole samples for water-quality parameters from monitoring wells and residential-supply wells, Savage Superfund Site, Milford, New Hampshire

5. Results of dissolved gas in groundwater from monitoring and residential wells, Savage Superfund Site, Milford, New Hampshire

6. Ranking of groundwater samples from wells based on results of chemical analyses and the potential of capturing long flowpaths, Savage Superfund Site, Milford, New Hampshire 


\section{Conversion Factors, Datums, and Abbreviations}

Inch/Pound to SI

\begin{tabular}{lcl}
\hline \multicolumn{1}{c}{ Multiply } & \multicolumn{1}{c}{ By } & \multicolumn{1}{c}{ To obtain } \\
\hline inch (in.) & Length & \\
foot (ft) & 2.54 & centimeter $(\mathrm{cm})$ \\
mile (mi) & 0.3048 & meter (m) \\
\hline & 1.609 & kilometer $(\mathrm{km})$ \\
\hline gallon (gal) & Volume & \\
liter (L) & 3.785 & liter $(\mathrm{L})$ \\
\hline & 33.82 & ounce, fluid (fl. oz) \\
\hline cubic foot per second $\left(\mathrm{ft}^{3} / \mathrm{s}\right)$ & Flow rate & \\
gallon per minute $(\mathrm{gal} / \mathrm{min})$ & 0.02832 & cubic meter per second $\left(\mathrm{m}^{3} / \mathrm{s}\right)$ \\
\hline & 0.06309 & liter per second $(\mathrm{L} / \mathrm{s})$ \\
\hline micrograms per liter $(\mu \mathrm{g} / \mathrm{L})$ & Concentration & \\
milligrams per liter $(\mathrm{mg} / \mathrm{L})$ & 1.00 & parts per billion $(\mathrm{ppb})$ \\
\hline & 1.00 & parts per million $(\mathrm{ppm})$ \\
\hline kilogram $(\mathrm{kg})$ & Mass & \\
megagram $(\mathrm{Mg})$ & 2.205 & pound avoirdupois $(\mathrm{lb})$ \\
\hline
\end{tabular}

Temperature in degrees Celsius $\left({ }^{\circ} \mathrm{C}\right)$ may be converted to degrees Fahrenheit $\left({ }^{\circ} \mathrm{F}\right)$ as follows: ${ }^{\circ} \mathrm{F}=\left(1.8 \mathrm{x}^{\circ} \mathrm{C}\right)+32$

Temperature in degrees Fahrenheit $\left({ }^{\circ} \mathrm{F}\right)$ may be converted to degrees Celsius $\left({ }^{\circ} \mathrm{C}\right)$ as follows: ${ }^{\circ} \mathrm{C}=\left({ }^{\circ} \mathrm{F}-32\right) / 1.8$

Vertical coordinate information is referenced to the National Geodetic Vertical Datum of 1929 (NGVD 29). Horizontal coordinate information is referenced to the North American Datum of 1983 (NAD 83).

Altitude, as used in this report, refers to distance above the vertical datum.

Volumes of liquid are given in milliliters $(\mathrm{mL})$

Delta notation for reporting of isotope data.-Stable isotope data are reported as a ratio relative to the ratio of a standard. For example, ${ }^{18} \mathrm{O} /{ }^{16} \mathrm{O}$ of a sample is compared with ${ }^{18} \mathrm{O} /{ }^{16} \mathrm{O}$ of a standard by the relation: $\delta^{18} \mathrm{O}=($ Rsample/Rstandard -1$) \times 1,000$, where Rsample $={ }^{18} \mathrm{O} / 16 \mathrm{O}$ in the sample, Rstandard $=18 \mathrm{O} / 160 \mathrm{O}$ the standard, and $\delta^{18} \mathrm{O}=$ relative difference in concentration, in parts per thousand (per mil).

Delta ${ }^{18} \mathrm{O}\left(\delta^{18} \mathrm{O}\right)$ is referred to as delta notation and is the value reported by isotopic laboratories for stable isotope analysis. Delta $D$ (also designated as $\delta^{2} \mathrm{H}$ ) or deuterium can be derived by analogy to $\delta^{18} \mathrm{O}$

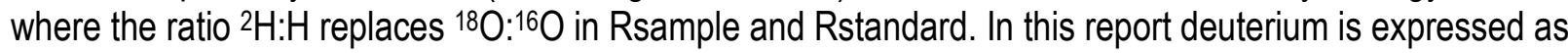
$\delta D$. The standard used for determining $\delta^{18} \mathrm{O}$ and $\delta \mathrm{D}$ in water originally was standard mean ocean water (SMOW) as defined by Craig (1961). The standard used in this report is Vienna standard mean ocean water (VSMOW). If $\delta^{18} \mathrm{O}$ and $\delta \mathrm{D}$ samples contain more of the heavier isotopes $\left({ }^{18} \mathrm{O}\right.$ or $\left.{ }^{2} \mathrm{H}\right)$ than the reference material, the samples have positive per mil values and are referred to as heavier than the reference material or as being enriched in the heavier isotope. Conversely, if the samples contain more of the lighter isotopes $\left({ }^{16} \mathrm{O}\right.$ or $\left.\mathrm{H}\right)$ than the reference material, the samples have negative per mil values and are referred to as lighter than the reference material or as being depleted in the heavier isotope. For 
example, a $\delta^{18} \mathrm{O}$ value of -18.15 per mil can be referred to as lighter than VSMOW or depleted in ${ }^{18} \mathrm{O}$ relative to VSMOW. Once the reference material has been specified, it is assumed by convention that all values are reported relative to it unless otherwise indicated.

Dissolved inorganic carbon $(\mathrm{DIC})$ of carbon-13 $\left(\delta^{13} \mathrm{C}\right)$ is reported relative to the Vienna Peedee Belemnite (VPDB) standard and expressed in per mil. The carbon-13 standard is -25 per mil VPDB; VPDB is the carbonate standard derived from the Rostrum of Belemnitella Americana of the Peedee Formation in South Carolina. Because values are reported relative to the reference material, samples with positive per mil values are referred to as heavier than the reference material or as being enriched in the heavier isotope. Conversely, if the samples contain more of the lighter isotopes than the reference material, the samples have negative per mil values and are referred to as lighter than the reference material or as being depleted in the heavier isotope.

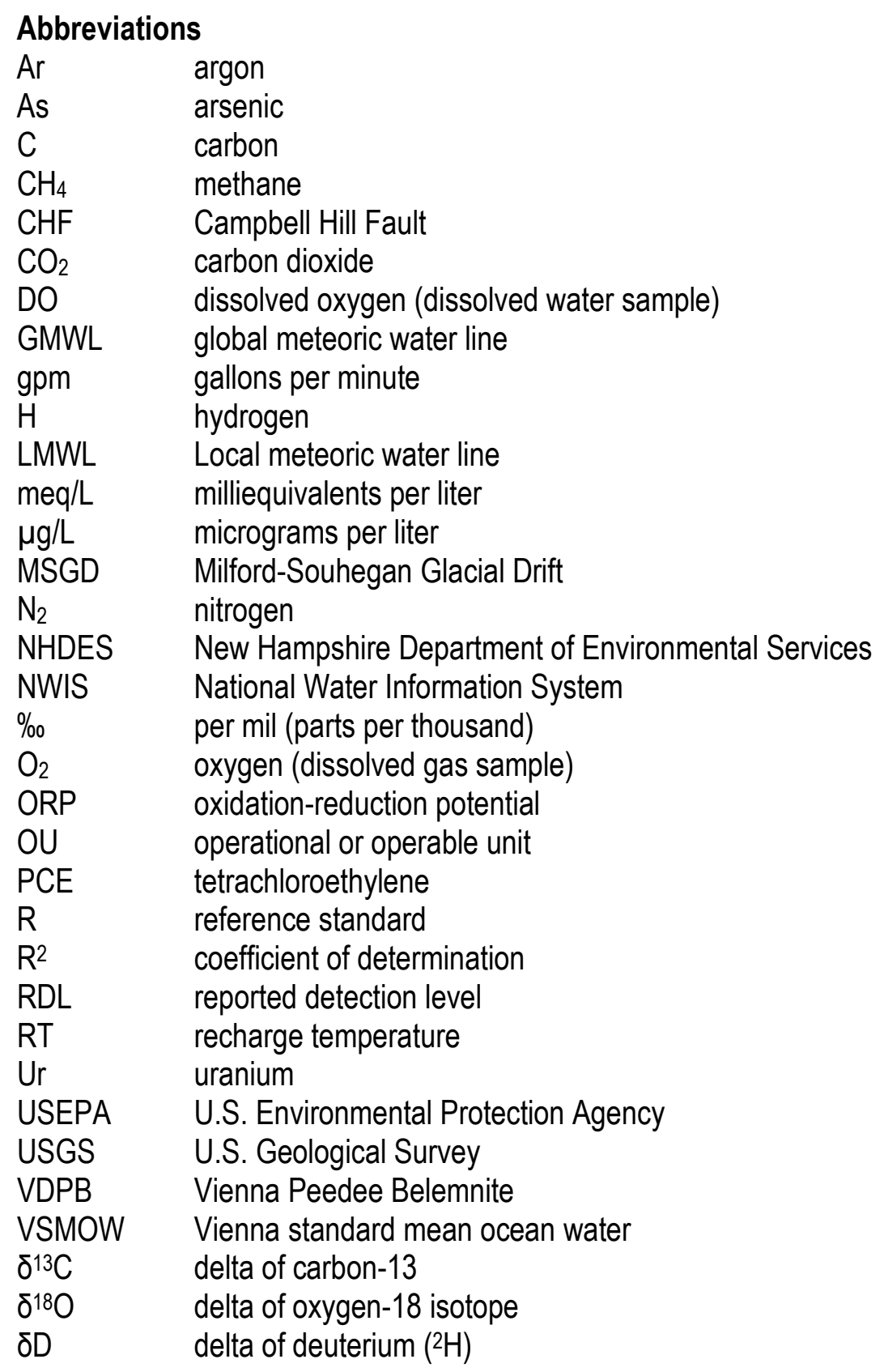




\title{
Geochemical, Isotopic, and Dissolved Gas Characteristics of Groundwater in a Fractured Crystalline-Rock Aquifer, Savage Municipal Well Superfund Site, Milford, New Hampshire, 2011
}

\author{
By Philip T. Harte
}

\section{Introduction}

Tetrachloroethylene (PCE), a volatile organic compound, was detected in groundwater from deep (more than $(>) 300$ feet (ft) below land surface) fractures in monitoring wells tapping a crystallinerock aquifer beneath operable unit $1^{1}$ (OU1) of the Savage Municipal Well Superfund site (Weston, Inc., 2010). Operable units define remedial areas of contaminant concern. PCE contamination within the fractured-rock aquifer has been designated as a separate operable unit, operable unit 3 (OU3; Weston, Inc., 2010). PCE contamination was previously detected in the overlying glacial sand and gravel deposits and basal till, hereafter termed the Milford-Souhegan glacial-drift (MSGD) aquifer (Harte, 2004, 2006). Operable units 1 and $2^{2}$ encompass areas within the MSGD aquifer, whereas the extent of the underlying OU3 has yet to be defined. The primary original source of contamination has been identified as a former manufacturing facility — the OK Tool manufacturing facility; hence OU1 sometimes has been referred to as the OK Tool Source Area (New Hampshire Department of Environmental Services, undated).

A residential neighborhood of 30 to 40 houses is located in close proximity (one-quarter of a mile) from the PCE-contaminated monitoring wells (fig. 1). Each house has its own water-supply well installed in similar rocks as those of the monitoring wells, as indicated by the New Hampshire State geologic map (Lyons and others, 1997). An investigation was initiated in 2010 by the U.S. Environmental Protection Agency (USEPA) region 1, and the New Hampshire Department of Environmental Services (NHDES) to assess the potential for PCE transport from known contaminant locations (monitoring wells) to the residential wells.

The U.S. Geological Survey (USGS) and the NHDES entered into a cooperative agreement in 2011 to assist in the evaluation of PCE transport in the fractured-rock aquifer. Periodic sampling over the last decade by the USEPA and NHDES has yet to detect PCE in groundwater from the residentialsupply wells (as of 2012). However, part of assessing the potential for PCE transport involves understanding the origin of the groundwater in the monitoring and residential wells. One of the tools in delineating the movement of groundwater to wells, particularly in complex, highly heterogeneous fractured-rock aquifers, is the understanding of the geochemical and isotopic composition of groundwater (Lipfert and Reeve, 2004; Harte and others, 2012). This report summarizes findings from

\footnotetext{
${ }^{1}$ OU1 designates the primary source area of PCE for the Savage Municipal Well Superfund site.

${ }^{2} \mathrm{OU} 2$ designates the extended plume area of PCE for the Savage Municipal Well Superfund site.
} 
analyses of geochemical, isotopic, and dissolved gas characteristics of groundwater. Samples of groundwater were collected in 2011 from monitoring wells and nearby residential-supply wells in proximity to OU1.

\subsection{Well Construction}

Construction information on the sampled wells (table 1) was derived from driller logs for the monitoring wells and from NHDES reports for the residential wells (Genevieve Al-Egaily, New Hampshire Department of Environmental Services, written commun., August 2, 2010). Most monitoring wells also were logged with a suite of borehole geophysical tools, which helped verify well construction information (Weston, Inc., 2012). All sampled wells are openly connected (open borehole) to the fractured-rock aquifer. The length of each open borehole can be determined by subtracting casing length from well depth (table 1). The maximum open-borehole length, $520 \mathrm{ft}$, is at DW-24. Wells are typically cased with 6-inch-diameter steel pipe that penetrates through the overlying MSGD aquifer and extends at least $10 \mathrm{ft}$ into the underlying rock.

The reported well yields ranged from 1.5 (well DW-12) to 100 (well DW-17) gallons per minute (gpm), based on drilling records (table 1). These yields may not reflect the yield capability of the aquifer under steady state conditions (equilibrium conditions) because part of the yield is likely from storage (well and aquifer) and represents a short-term (hours to days) yield. Nevertheless, reported yields are useful to assess the relative water yielding capability of each well.

\subsection{Geology, Fracture Characteristics, and Lineaments}

The fractured-rock aquifer consists of tonalite, granite, and gneiss (Lyons and others, 1997). Tonalite is mapped to the west and is coincident with the higher terrain in the study area. Tonalite is separated from the rocks to the east (granite and gneiss) by the Campbell Hill Fault ${ }^{3}$ (CHF; fig. 1). The fault is primarily a normal fault that also may have a strike slip component (William C. Burton, U.S. Geological Survey, written commun., 2013). Granite and gneiss occur in the valley (Lyons and others, 1997).

The residential and monitoring wells are intersected by multiple fractures over the length of the open borehole. Mixing of groundwater, therefore, occurs in the borehole from the contribution of groundwater from multiple fractures. Mixing can complicate the analysis of results from well water samples because they represent composite (integrated) samples.

Fractures are predominantly northeast striking and steeply inclined ( $>45$ degrees) (Weston, Inc., 2012; William C. Burton, U.S. Geological Survey, written commun., 2013). The location of the study area on the western limb of the Massabesic anticlinorium is likely a major factor in the number of foliation features that dip to the northwest (William C. Burton, U.S. Geological Survey, written commun., 2013).

Lineaments are linear features seen on the surface of the Earth with remotely sensed imagery. They are potentially related to structural features and high water-yielding zones within the bedrock (Mabee and Hardcastle, 1997). Lineaments were mapped in the study area by Clark and others (1997) and are shown on figure 1. Several wells are close (within $100 \mathrm{ft}$ ) to lineaments or the CHF including DW-2, DW-17, DW-12, DW-5A, DW-6, DW-9A, DW-19, and DW-18. Several of these wells (called lineament wells), DW-2 (15 gpm) and DW-17 (100 gpm), have high yields (table 1), whereas several of the other wells have relatively low yields (less than $(<) 10 \mathrm{gpm}$ ). In contrast, four of the eight wells that are not within $100 \mathrm{ft}$ of the mapped lineaments have high yields. The mean yield between

\footnotetext{
${ }^{3}$ The location of the CHF is approximate and has been remapped (William C. Burton, U.S. Geological Survey, written commun., 2013).
} 
wells located proximal $(<100 \mathrm{ft})$ and distal $(>100 \mathrm{ft})$ to lineaments or the CHF is 19.8 and $18.8 \mathrm{gpm}$, respectively. The difference is not significant at the 95-percent confidence interval (p-value of 0.477 based on t-test for unequal variance).

Table 1. Well construction for sampled wells, OU3 Savage Municipal Well Superfund site, Milford, New Hampshire.

[Well type: R, residential well; M, monitoring well. Sample type: C, general chemistry sample collected; I, isotope sample collected. Altitude of land surface is in feet (ft) above the National Geodetic Vertical Datum of 1929 (NGVD 29). gpm, gallons per minute; NHDES, New Hampshire Department of Environmental Services; OU3, operations unit 3; --, no data]

\begin{tabular}{|c|c|c|c|c|c|c|}
\hline NHDES well identifier ${ }^{1}$ & Well type & $\begin{array}{c}\text { Sample } \\
\text { type }\end{array}$ & $\begin{array}{l}\text { Altitude of } \\
\text { land surface } \\
\text { (ft) }\end{array}$ & $\begin{array}{l}\text { Length of } \\
\text { casing (ft) }\end{array}$ & $\begin{array}{l}\text { Depth of } \\
\text { well (ft) }\end{array}$ & $\begin{array}{l}\text { Well yield } \\
\text { (gpm) }\end{array}$ \\
\hline OKT_DW-17 & $\mathrm{R}$ & $\mathrm{C}, \mathrm{I}$ & 303 & 60 & 240 & 100 \\
\hline OKT_DW-9A & $\mathrm{R}$ & $\mathrm{C}, \mathrm{I}$ & 290 & 120 & 360 & 5 \\
\hline OKT_DW-5A & $\mathrm{R}$ & $\mathrm{C}, \mathrm{I}$ & 285 & 76 & 340 & 5 \\
\hline OKT_DW-6 & $\mathrm{R}$ & $\mathrm{C}, \mathrm{I}$ & 290 & -- & 450 & -- \\
\hline OKT_DW-2 & $\mathrm{R}$ & $\mathrm{C}, \mathrm{I}$ & 290 & 130 & 420 & 15 \\
\hline OKT_DW-27 & $\mathrm{R}$ & $\mathrm{C}$ & 272 & -- & -- & -- \\
\hline OKT_DW-18 & $\mathrm{R}$ & $\mathrm{C}$ & 295 & 123 & 320 & 8.5 \\
\hline OKT_DW-20 & $\mathrm{R}$ & $\mathrm{C}$ & 292 & 135 & 240 & 8 \\
\hline OKT_DW-24 & $\mathrm{R}$ & C,I & 380 & 180 & 700 & 10 \\
\hline OKT_DW-25 & $\mathrm{R}$ & C,I & 319 & 102 & 500 & 20 \\
\hline OKT_DW-23 & $\mathrm{R}$ & $\mathrm{C}$ & 311 & 102 & 300 & 5 \\
\hline OKT_DW-21 & $\mathrm{R}$ & $\mathrm{C}$ & 279 & 115 & 320 & 5 \\
\hline OKT_DW-22 & $\mathrm{R}$ & $\mathrm{C}$ & 300 & 103 & 320 & 3 \\
\hline OKT_DW-12 & $\mathrm{R}$ & C,I & 288 & 123 & 420 & 1.5 \\
\hline OKT_DW-19 & $\mathrm{R}$ & $\mathrm{C}$ & 289 & 112 & 300 & 3.5 \\
\hline OKT_DW-29 & $\mathrm{R}$ & $\mathrm{C}, \mathrm{I}$ & 265 & 95 & 300 & 75 \\
\hline OKT_DW-30 & $\mathrm{R}$ & $\mathrm{C}$ & 265 & 100 & 500 & 25 \\
\hline OKT_DW-28 & $\mathrm{R}$ & $\mathrm{C}$ & 275 & -- & -- & -- \\
\hline OKT_BR-4 & M & $\mathrm{C}, \mathrm{I}$ & 269 & 138 & 420 & -- \\
\hline OKT_MW-30 & M & C,I & 268 & 160 & 304 & -- \\
\hline OKT_BR-3 & $\mathrm{M}$ & $\mathrm{C}, \mathrm{I}$ & 275 & 134 & 400 & -- \\
\hline
\end{tabular}

${ }^{1}$ The "OKT_" prefix is omitted in remainder of report. Location of wells shown in figure 1.

\subsection{Well Identifier}

The well identification system used in this report follows the NHDES record system (table 1 and appendix 1). The USGS uses a station (site) name identification system in addition to the NHDES identifier (appendix 1). The USGS station (site) name can be used to access well data through the National Water Information System (NWIS; http://nwis.waterdata.usgs.gov/nwis). 


\section{Methods of Well Sampling and Analysis}

Three monitoring wells and 18 residential-supply wells were sampled in 2011 (table 1). Monitoring wells (BR-3, BR-4, and MW-30) were sampled by purging and sampling of the entire open borehole according to methods described in NHDES sample analysis plan (New Hampshire Department of Environmental Services, 2011). Typically, 50 gallons of water were purged at approximately 1 to 2 gpm prior to sampling (New Hampshire Department of Environmental Services, 2011). For a 6-inch diameter well, 50 gallons (gal) is equivalent to evacuating approximately $34 \mathrm{ft}$ of water column within the open borehole. After 50 gal was purged, pump rates were decreased and sampling began. This procedure is meant to mimic a pumping cycle in a residential-supply well (New Hampshire Department of Environmental Services, 2011). All monitoring wells were previously sampled with a packer and pump assembly that allowed for the collection of samples from discrete fracture intervals (Weston, Inc., 2010); these data are discussed in the "Results of Geochemical, Isotopic, and Dissolved Gas Analyses" section below.

Residential-supply wells were sampled according to methods described in New Hampshire Department of Environmental Services (2011).Wells were purged by using the existing well pump and water system infrastructure of the home and samples collected before any household treatment system. The open boreholes of the residential-supply wells are frequently recharged from daily pumping, unlike monitoring wells, which are infrequently purged (only a few times over their well history).

Water-quality field parameters ( $\mathrm{pH}$, specific conductance, water temperature, oxidationreduction potential (ORP), DO, and turbidity) were measured with an YSI Model 600XL or 6820 meter in the field. Meters were calibrated as described in New Hampshire Department of Environmental Services (2011). Water-quality field parameters were collected prior to sampling for the other chemical constituents. Only the final set of readings was recorded by field personnel (New Hampshire Department of Environmental Services, 2011). Therefore, the temporal chemical variability of groundwater during purging cannot be assessed.

Duplicate and equipment blank samples were collected according to methods described in New Hampshire Department of Environmental Services (2011). Duplicates were collected in the field immediately after initial sample collection. Laboratory spikes were performed according to NHDES laboratory procedures for most of the chemical constituents analyzed for this study.

A listing of the constituents analyzed (nonisotopic only), methods of analyses, regulatory action limits, and laboratory reporting levels is provided in table 2. In general, samples were unfiltered and collected into preacidified bottles to prevent precipitation of metals and other constituents. In addition to the chemical constituents listed in table 2, USEPA and NHDES routinely sample for volatile organic compounds (USEPA schedule 8260). A discussion of volatile organic compounds is presented in Weston, Inc. (2012). All water-quality (nonisotopic) data reported in this report also are included in the Weston, Inc. (2012) report.

Groundwaters from a subset of the residential wells ( 9 of the18) and all three monitoring wells were sampled, and samples were analyzed for isotopes of carbon, oxygen, and hydrogen and selected dissolved gases (fig. 1). Isotope samples were collected according to USGS procedures and analyses were performed in the U.S. Geological Survey Stable Isotope Laboratory in Reston, Va. Stable isotopes of $\delta \mathrm{D}$ were measured by using a hydrogen equilibration technique (Coplen and others, 1991; Révész and Coplen, 2008a). Stable isotopes of $\delta^{18} \mathrm{O}$ were measured by using the $\mathrm{CO}_{2}$ equilibration technique of Epstein and Mayeda (1953), and Révész and Coplen (2008b). Analytical results are reported as $\delta \mathrm{D}$ and $\delta^{18} \mathrm{O}$ (per mil, relative to VSMOW) with 1-sigma uncertainties of 1 per mil for $\delta \mathrm{D}$ and 0.1 per mil for $\delta^{18} \mathrm{O}$. These samples were collected unfiltered and untreated in 150-mL glass bottles. Dissolved inorganic carbon-13 $\left(\delta^{13} \mathrm{C}\right)$ was analyzed according to methods described in U.S. Geological Survey 
(2012b) and St-Jean (2003). These samples were collected filtered and treated in 40-mL (milliliter) vial septum bottles.

Additional samples were collected for analysis of dissolved gases $\left(\mathrm{Ar}, \mathrm{N}_{2}, \mathrm{CH}_{4}\right.$, and $\left.\mathrm{CO}_{2}\right)$. Dissolved gases were analyzed in the USGS Chlorofluorocarbon Laboratory in Reston, Va., by using gas chromatography procedures (U.S. Geological Survey, 2012a; Busenberg and others, 1998; $\mathrm{http} / / /$ water.usgs.gov/lab/cfc/). Samples were collected unfiltered and untreated in 150-mL septum bottles that were filled while submerged in water, thus without headspace.

Table 2. Chemical constituents, reporting limits and regulatory standards, OU3 Savage Municipal Well Superfund site, Milford, New Hampshire.

[All concentrations in milligrams per liter. AGQS, Ambient Groundwater Quality Standards; Env-Or600, New Hampshire Department of Environmental Services environmental rule (September 2008); N/A, not applicable; RDL, reporting detection limit; OU3, operations unit 3; USEPA, U.S. Environmental Protection Agency;--, no standard]

\begin{tabular}{|c|c|c|c|c|}
\hline Test methods & Analytes & $\begin{array}{c}\text { Interim cleanup } \\
\text { levels for } \\
\text { Savage site }\end{array}$ & $\begin{array}{c}\text { NHDES AGQS } \\
\text { (Env-Or-600) }\end{array}$ & Lab RDLs \\
\hline \multirow[t]{6}{*}{ Total metals by USEPA method $200.7 / 200.8$} & Arsenic & 0.05 & 0.01 & 0.001 \\
\hline & Antimony & 0.003 & 0.006 & 0.003 \\
\hline & Beryllium & 0.001 & 0.004 & 0.001 \\
\hline & Chromium & 0.1 & 0.1 & 0.005 \\
\hline & Lead & 0.015 & 0.015 & 0.001 \\
\hline & Nickel & 0.1 & 0.1 & 0.005 \\
\hline \multirow[t]{7}{*}{ Total metals by USEPA method $200.7 / 200.8$} & Calcium & N/A & -- & 1 \\
\hline & Iron & N/A & -- & 0.05 \\
\hline & Magnesium & N/A & -- & 0.1 \\
\hline & Manganese & $\mathrm{N} / \mathrm{A}$ & 0.84 & 0.01 \\
\hline & Potassium & N/A & 35 & 0.25 \\
\hline & Sodium & N/A & -- & 1 \\
\hline & Uranium & N/A & -- & 1 \\
\hline USEPA method 200.7 & Dissolved iron & N/A & -- & 0.05 \\
\hline USEPA 415.3 & Total organic carbon & N/A & -- & 0.5 \\
\hline USEPA SM 2320B & Alkalinity & N/A & -- & 1 \\
\hline Ion chromatography, Lachat $10-117-07-1-\mathrm{B}^{1}$ & Chloride & N/A & -- & 3 \\
\hline Ion chromatography, Lachat $10-107-04-1-\mathrm{C}^{1}$ & Nitrate & $\mathrm{N} / \mathrm{A}$ & 10 & 0.05 \\
\hline Ion chromatography, Lachat $10-107-04-1-\mathrm{C}^{1}$ & Nitrite & $\mathrm{N} / \mathrm{A}$ & 1 & 0.05 \\
\hline Ion chromatography, Lachat $10-107-04-1-\mathrm{C}^{1}$ & Nitrate and nitrite & $\mathrm{N} / \mathrm{A}$ & -- & 0.05 \\
\hline Ion chromatography, Lachat $10-510-00-1-\mathrm{E}^{1}$ & Sulfate & $\mathrm{N} / \mathrm{A}$ & 500 & 1 \\
\hline Ion chromatography, Lachat $10-510-00-1-\mathrm{E}^{1}$ & Bromide & N/A & -- & 0.1 \\
\hline Ion chromatography, Lachat $10-109-12-2-\mathrm{A}^{1}$ & Fluoride & N/A & 4 & 0.2 \\
\hline
\end{tabular}

${ }^{1}$ Lachat instrument (http://www.lachatinstruments.com/download/LL022-Methods-List_5-10.pdf).

\section{Results of Geochemical, Isotopic, and Dissolved Gas Analyses}

Results are first presented for a comparison between open-borehole samples (collected for this study) and discrete fractures samples (collected by a previous study, Weston, Inc., 2010) from the three monitoring wells. This comparison was done to assess whether open-borehole samples are representative of groundwater from the fractured rock. Water-quality field parameters (specific conductance, $\mathrm{pH}, \mathrm{ORP}$ (oxidation-reduction potential), dissolved oxygen (DO), temperature, and turbidity) are discussed first, followed by a discussion of general geochemistry (major ions), isotopes, and dissolved gases. Some trace-ion chemistry was also collected (Ur, As). Uranium was detected above the reported detection level (RDL of $1 \mu \mathrm{g} / \mathrm{L}$ ) in all samples and had a maximum concentration of 60 
$\mu \mathrm{g} / \mathrm{L}$ (Weston, Inc., 2012). Arsenic was non-detect (RDL of $1 \mu \mathrm{g} / \mathrm{L}$ ) in all samples except for two and had a maximum concentration of $8.1 \mu \mathrm{g} / \mathrm{L}$ (Weston, Inc., 2012).

\subsection{Comparison of Open-Borehole and Discrete Fracture Samples}

The specific conductance values of well water derived from the three open-borehole samples were within the range of specific conductance from discrete fracture samples at 2 of the 3 monitoring wells (table 3). However, $\mathrm{pH}$, ORP, DO, and to a lesser extent, temperature, differ between open borehole and discrete fracture samples. The $\mathrm{pH}$ of the open-borehole samples was less than the ranges of $\mathrm{pH}$ from the discrete fracture samples; the same relation was true for DO. The ORP of the openborehole sample was within the range of ORP from fracture samples for BR-3 but outside the range for BR-4 and MW-30. Temperature from the open-borehole samples was similar in 1 of 3 wells. Uranium concentrations also were similar for both sets of samples from BR-3.

Table 3. Results of open-borehole and fracture specific samples for water-quality parameters from monitoring wells, Savage Municipal Well Superfund site, Milford, New Hampshire.

$\left[\mu \mathrm{s} / \mathrm{cm}\right.$, microsiemens per centimeter at 25 degrees Celsius $\left({ }^{\circ} \mathrm{C}\right)$; ORP, oxidation-reduction potential; $\mathrm{mV}$, millivolts; DO, dissolved oxygen; $\mathrm{mg} / \mathrm{L}$, milligrams per liter; $\mu \mathrm{g} / \mathrm{L}$, micrograms per liter; --, no data]

\begin{tabular}{|c|c|c|c|c|c|c|c|}
\hline Well ${ }^{1}$ & Zone & $\begin{array}{c}\text { Specific } \\
\text { conductance } \\
\text { range } \\
(\mu \mathrm{s} / \mathrm{cm})\end{array}$ & $\mathrm{pH}$ range & $\begin{array}{l}\text { ORP range } \\
(\mathrm{mV})\end{array}$ & $\begin{array}{c}\text { DO range } \\
\text { (mg/L) }\end{array}$ & $\begin{array}{c}\text { Temperature } \\
\text { range }\left({ }^{\circ} \mathrm{C}\right)\end{array}$ & $\begin{array}{l}\text { Uranium } \\
\text { range } \\
\text { ( } \mu \mathrm{g} / \mathrm{L})\end{array}$ \\
\hline BR-3 & Open borehole & 237 & 7.18 & 55 & 0.5 & 12.9 & 7 \\
\hline \multirow[t]{2}{*}{$\mathrm{BR}-4$} & Discrete fracture (ranges) & $222-234$ & $8.51-8.77$ & $67-85$ & $1.7-3.9$ & $9.9-11.0$ & -- \\
\hline & Open borehole & 247 & 7.77 & 10 & 0.2 & 9.8 & 26 \\
\hline
\end{tabular}

${ }^{1}$ Location of wells shown in figure 1.

The results of the comparison between open-borehole and discrete fracture samples suggest that the open-borehole samples may not reflect recent recharge from fractures. The purging method for the open-borehole samples is less than ideal because only 10 percent of a typical well volume is withdrawn prior to sample collection (New Hampshire Department of Environmental Services, 2011), and the samples may represent borehole water that is stagnant within the well or derived from poorly connected fractures.

The DO concentration of the open-borehole samples are approximately $1 / 8$ to $1 / 3$ the value of the fracture samples. The open-borehole samples likely contain some stagnant borehole water or water derived from poorly connected fractures. The median DO concentration in water from 115 residentialsupply wells in New England crystalline rocks was $1.9 \mathrm{mg} / \mathrm{L}$ (Flanagan and others, 2012); the DO concentration in water from fracture samples (table 3) were comparable to residential-supply well samples from this study. The amount of stagnant water in residential-supply wells should be relatively low and, therefore, the similarity in DO concentrations in residential and fracture samples supports the theory of recent recharge from fractures (hydraulically connected fractures) in both sets of samples. In New England crystalline-rock aquifers, an inverse relation has been demonstrated between residence time and DO concentrations in groundwater: old waters had low DO concentrations. This also supports the theory of low DO concentrations in poorly connected fractures (Harte and others, 2008). 


\subsection{Water-Quality Field Parameters}

Specific conductance, $\mathrm{pH}, \mathrm{ORP}, \mathrm{DO}$, turbidity, and water temperature are physiochemical properties of water that can affect the mobility of trace elements in groundwater (Flanagan and others, 2012). These properties vary in water from the crystalline-rock aquifer at the site depending on the physical and chemical characteristics of soil and of aquifer materials, fracture flow (such as whether water being pumped originates from short or long flowpaths), residence time of groundwater, and inputs from anthropogenic sources such as road salting and septic leachate. Water-quality field parameters may also be affected by the frequency and amount of water withdrawn from the well and how the sample was collected.

Given the differences in the number of samples between monitoring and residential-supply wells, it is to be expected that the ranges in values of field parameters were much larger for the residential-supply well samples than the monitoring well samples, particularly for DO and turbidity (table 4). The DO of the samples from monitoring wells was less than $1 \mathrm{mg} / \mathrm{L}$, whereas 6 of 18 samples from the residential-supply wells were greater than $1 \mathrm{mg} / \mathrm{L}$. Differences in withdrawals between monitoring and residential wells likely affect DO, as discussed in section 3.1 (Water-Quality Field Parameters). Turbidity was much greater in the monitoring well samples than in the residential-supply well samples. A high of 801 NTU (nephelometric turbidity units) was measured at MW-30 (fig. 1).

Table 4. Results of open-borehole samples for water-quality parameters from monitoring wells and residentialsupply wells, Savage Municipal Well Superfund site, Milford, New Hampshire.

[DO, dissolved oxygen; $\mathrm{mg} / \mathrm{L}$, milligrams per liter; $\mathrm{mV}$, millivolts; $\mu \mathrm{s} / \mathrm{cm}$, microsiemens per centimeter at 25 degrees Celsius $\left({ }^{\circ} \mathrm{C}\right)$; NTU, nephelometric turbidity units; ORP, oxidation-reduction potential; <, less than]

\begin{tabular}{cccccccc}
\hline Well & Number of wells & $\begin{array}{c}\text { Specific } \\
\text { conductance } \\
\text { range }(\boldsymbol{\mu s} / \mathrm{cm})\end{array}$ & $\mathrm{pH}$ range & $\begin{array}{c}\text { ORP range } \\
(\mathrm{mV})\end{array}$ & $\begin{array}{c}\text { Do range } \\
(\mathbf{m g} / \mathrm{L})\end{array}$ & $\begin{array}{c}\text { Temperature } \\
\text { range }\left({ }^{\circ} \mathrm{C}\right)\end{array}$ & $\begin{array}{c}\text { Turbidity } \\
\text { range (NTU } \\
\text { units) }\end{array}$ \\
\hline Monitoring & 3 & $213-247$ & $7.18-8.45$ & $10-55$ & $0.2-0.6$ & $9.8-12.9$ & $28-801$ \\
Residential & 18 & $142-328$ & $6.94-8.22$ & $-7-185$ & $* 0.2-8.3$ & $10.8-15.3$ & $<1-13$ \\
\hline
\end{tabular}

*DO concentrations in 6 of 18 samples were greater than $1 \mathrm{mg} / \mathrm{L}$.

\subsection{Major-Ion Geochemical Analysis}

Major-ion chemistry is useful for the designation of water type and identification of general water composition and reactions. Piper (trilinear) diagrams (Piper, 1944) are a helpful visual tool in the identification of water type; they include two ternary diagrams, one for major cations and the other for major anions in percentage of major ions in milliequivalents per liter $(\mathrm{meq} / \mathrm{L})$. The position of the water composition of the sampled water on the two ternary diagrams is then projected onto a third diagram.

Water type was identified for the sampled groundwater and compared to four parameters associated with each well: altitude of land surface (elevation), well depth, yield, and rock type. Rock type was differentiated based on the location of wells relative to three geologic features: either granite or gneiss rocks, proximity to fracture zone (within $100 \mathrm{ft}$ ), and tonalite rock as mapped according to the geologic map of New Hampshire (Lyons and others, 1997).

Results show groundwater ranges from a calcium-bicarbonate water type to a sodiumbicarbonate water type (fig. 2). The composition and distribution of water types suggests groundwater is chemically evolving as a result of cation exchange of calcium with sodium. Therefore, groundwater characterized as a calcium-bicarbonate water type can be viewed as relatively "chemically immature" whereas groundwater characterized as a sodium-bicarbonate water type can be viewed as relatively "chemically mature." For the fractured-rock aquifer at this site, chemically mature water essentially 
means that some of the groundwater from a single or multiple fractures had sufficient time for cation exchange reactions to occur.

The water type at monitoring wells BR-4 and MW-30 indicate a relatively chemically mature water composition. In addition, the relatively high $\mathrm{pH}$ of these waters (table 3 ) is consistent with more highly evolved water from the crystalline-rock aquifers of New England (Flanagan and others, 2012). Wells BR-4 and MW-30 are between the residential wells and monitoring well BR-3 (fig. 1). BR-3 had high PCE concentrations $(>10,000 \mu \mathrm{g} / \mathrm{L}), \mathrm{BR}-4$ had no detectable PCE, and MW-30 had low concentrations $(<100 \mu \mathrm{g} / \mathrm{L})$ (Weston, Inc., 2012).

Depth of well and well yield appear to be a factor in water type, whereas the elevation of the well (altitude of land surface) and rock type show no particular water compositional pattern (fig. 3). Depth of well shows an inverse pattern with deep wells characterized as a calcium-bicarbonate water type; this suggests that the recharge water to these wells is relatively chemically immature. Although this relation appears contradictory, it is consistent with observations of water chemistry from deep wells with long open boreholes in fractured-rock aquifers (Harte and others, 2008). The deep wells generally are characteristic of low fracture frequency and low yields. In some cases, these wells have been shown to be recharged primarily by shallow fractures near the well casing, and the absence of fractures in the rock dictates that long open boreholes be drilled to ensure adequate storage for water-supply use. The pattern for yield shows that high-yield wells are primarily characterized as a calcium-bicarbonate water type, which indicates these wells were quickly recharged by relatively young groundwater (fig. 3).

\subsection{Isotopic Analysis}

Deuterium $(\delta \mathrm{D})$ and oxygen-18 $\left(\delta^{18} \mathrm{O}\right)$ provide information on sources of recharge to groundwater and show a high degree of correlation. Craig (1961) demonstrated this relation by the creation of a Global Meteoric Water Line (GMWL), expressed by the equation: $\delta \mathrm{D}=8 \delta^{18} \mathrm{O}+10 \%$. The GMWL is an average of many local relations of $\delta \mathrm{D}$ and $\delta^{18} \mathrm{O}$. Differential fractionation of $\delta \mathrm{D}$ and $\delta^{18} \mathrm{O}$ occurs as a function of humidity during primary evaporation of water vapor from the ocean and as a function of temperature during secondary evaporation as rain falls from a cloud (Kendall and Coplen, 2000). These two factors affect the local relation of $\delta \mathrm{D}$ and $\delta^{18} \mathrm{O}$, thereby producing a unique Local Meteoric Water Line (LMWL) at different locations (Benjamin and others, 2004). Kendall and Coplen (2000) developed an LMWL for New Hampshire that is expressed as $\delta \mathrm{D}=7.3 \delta^{18} \mathrm{O}+5.3 \%$. The latter LMWL is presented in selected graphs shown in this report. The values of $\delta^{18} \mathrm{O}$ and $\delta \mathrm{D}$ from precipitation are always negative because the reference standard (VSMOW) reflects the average isotopic composition of the ocean and distillation from evaporation leaves a residue of water with a heavy isotopic composition.

Measured $\delta \mathrm{D}$ and $\delta^{18} \mathrm{O}$ values from samples plot closely to the LMWL indicating that groundwater is recharged by meteoric water. Measured $\delta \mathrm{D}$ values varied by $-4.37 \%$ and $\delta^{18} \mathrm{O}$ varied by $-0.68 \%$. The $\delta \mathrm{D}$ and $\delta^{18} \mathrm{O}$ composition of groundwater from sampled wells are similar to values in river water for the northeastern United States (Kendall and Coplen, 2000) suggesting that groundwater from the study area was recently (less than 40 years) recharged. The isotopically lightest groundwater was from well DW-6 and the isotopically heaviest from well DW-5A. Wells DW-6 and DW-5A are closely located (fig. 1) but their water quality differs the most. Results illustrate the effect of heterogeneity in fractured-rock aquifers on groundwater flow and transport.

There is no distinguishing difference between the $\delta \mathrm{D}$ and $\delta^{18} \mathrm{O}$ composition of groundwater from the monitoring wells and many of the residential wells (fig. 4A). Groundwater from the monitoring wells had intermediate $\delta \mathrm{D}$ and $\delta^{18} \mathrm{O}$ values. Parameters associated with each well such as rock type, elevation of well (land surface), casing length, and depth of well showed no discernible pattern.

However, wells with the highest yields tended to have isotopically lighter $\delta \mathrm{D}$ and $\delta^{18} \mathrm{O}$ values (fig. 4B). 
The relation of yield to isotopic composition suggests that there is a temporal difference in recharge to some of the wells. Evapotranspiration in the warmer months preferentially distills $\delta \mathrm{D}$ and $\delta^{18} \mathrm{O}$ and produces a heavier isotope. Conversely, winter or early spring recharge from snowmelt produces a lighter isotope. Long-term averaging of recharge would produce intermediate $\delta \mathrm{D}$ and $\delta^{18} \mathrm{O}$ values. Samples from the monitoring wells exhibit an intermediate $\delta \mathrm{D}$ and $\delta^{18} \mathrm{O}$ composition, indicating a diffuse recharge pattern. The highest yielding wells likely receive a part of their recharge from a shorter "seasonal" time period unlike lower yielding wells, which likely receive diffuse recharge over a longer time period (years). In this study, the highest yielding wells likely receive a greater component of recharge from the preceding winter or early spring period (sampling occurred in August 2011). The exception is DW-17, which has an intermediate $\delta \mathrm{D}$ and $\delta^{18} \mathrm{O}$ composition that points to a bimodal (with equal contributions of light and heavy isotopes) mixing pattern of recharge. Groundwater with the heaviest $\delta \mathrm{D}$ and $\delta^{18} \mathrm{O}$ values (DW-5A, DW-12, and DW-9A) may receive a disproportionate part of their recharge from the summer compared to other wells with lighter isotopic composition.

Dissolved inorganic carbon (DIC) $\delta^{13} \mathrm{C}$ can help identify carbon sources and carbon reactions such as calcite dissolution. Carbon has two stable, naturally occurring isotopes: $\delta^{12} \mathrm{C}$ (98.89 percent) and $\delta^{13} \mathrm{C}(1.11$ percent $)$. The $\delta^{13} \mathrm{C}$ of the atmosphere is $-7 \%$. During photosynthesis, the carbon that becomes fixed in plant tissue is significantly depleted in $\delta^{13} \mathrm{C}$ relative to the atmosphere (Kendall and others, 1995). Isotope fractionation in the $\mathrm{CO}_{2}-\mathrm{HCO}_{3}-\mathrm{CaCO}_{3}$ geochemical system results in calcite that is enriched in $\delta^{13} \mathrm{C}$ by about $10 \%$ relative to $\mathrm{CO}_{2}$ at $20^{\circ} \mathrm{C}$. The $\delta^{13} \mathrm{C}$ values of dissolved inorganic carbon (DIC) in groundwater are generally in the range of -5 to $-25 \%$ (Mills, 1988; Kendall and others, 1995). The primary reactions that produce DIC are (1) weathering of carbonate minerals by acidic rain or other strong acids, (2) weathering of silicate minerals by carbonic acid produced by the dissolution of biogenic soil $\mathrm{CO}_{2}$ by infiltrating rain water; and, (3) weathering of carbonate minerals by carbonic acid.

Under favorable conditions, carbon isotopes can be used to understand the biogeochemical reactions controlling alkalinity in watersheds (Mills, 1988; Kendall and others, 1995). Carbon isotopes can also be useful tracers of the seasonal and discharge-related contributions of different hydrologic flowpaths to streamflow (Kendall and others, 1995). In many carbonate-poor watersheds, waters along shallow flowpaths in the soil zone have characteristically light $\delta^{13} \mathrm{C}$ values reflecting carbonic-acid weathering of silicates. Waters along deeper flowpaths within less weathered materials have intermediate $\delta^{13} \mathrm{C}$ values characteristic of carbonic-acid weathering of carbonates (Bullen and Kendall, 1998). Other processes that may complicate the interpretation of the $\delta^{13} \mathrm{C}$ values of surface waters and groundwater include $\mathrm{CO}_{2}$ degassing, input of soil gas $\mathrm{CO}_{2}$ from bacteria respiration, carbonate precipitation, exchange with atmospheric $\mathrm{CO}_{2}$, carbon uptake by aquatic organisms, methanogenesis, and methane oxidation (Bullen and Kendall, 1998).

Groundwater $\delta^{13} \mathrm{C}$ varied by approximately $-20 \%$, which is a fairly large range that indicates differences in contact time between the sampled groundwater and the various sources (carbonate minerals) or sinks of carbon (fig. 5). The contact time of groundwater is thought to be a limiting factor in $\delta^{13} \mathrm{C}$ composition rather than reaction time because reaction time is fairly quick in carbonate reactions (Kendall and others, 1995). In this report, contact time is defined as the interaction of spatiotemporal factors (flowpath length and travel time) with rock mineralogy. Therefore, differences in $\delta^{13} \mathrm{C}$ values reflect differences in flowpaths to the wells. Differences also are attributable to the effect of soil $\mathrm{CO}_{2}$ on groundwater, which generally lowers values of $\delta^{13} \mathrm{C}$ in groundwater to an equivalent $\delta^{13} \mathrm{C}$ value of the predominant organic matter in the soil (Doctor and others, 2008).

Monitoring well MW-30 (-5.09\%) is relatively enriched in $\delta^{13} \mathrm{C}$, which means groundwater from the well likely reacted with carbonate minerals. Conversely, DW-5A is relatively light in $\delta^{13} \mathrm{C}$ indicating little or less reaction with carbonates and/or substantial input of groundwater affected by soil 
gas $\mathrm{CO}_{2}$. Interestingly, DW-5A was isotopically heaviest in $\delta \mathrm{D}$ and $\delta^{18} \mathrm{O}$ indicating the well was recharged by shallow groundwater that was exposed to evapotranspiration during the summer months. Monitoring wells BR-3 and BR-4 have isotopically similar $\delta^{13} \mathrm{C}$ composition as many of the residential wells.

\subsection{Dissolved Gas Analysis}

Dissolved gas measurements also are useful for the determination of geochemical reactions along flowpaths. Analysis of dissolved gases, particularly noble gases, allow for the determination of recharge areas and seasonal period of recharge that the sample entered the groundwater. Other dissolved gases help identify biogeochemical reactions like methanogenesis and denitrification.

The concentrations of dissolved gases, as specified by the mean and standard deviation from repeated measurements of the same gas samples, are provided in table 5. Oxygen concentrations were generally less than $0.5 \mathrm{mg} / \mathrm{L}$, which is consistent with water-quality field measurements of DO although biological oxygen demand could suppress DO in lab measurements. Methane generally was low (except for groundwater at MW-30) indicating low methanogenic activity. Conversely, $\mathrm{CO}_{2}$ shows a two-order magnitude range in values. High $\mathrm{CO}_{2}$ occurred at DW-17, which is the highest yielding well (100 gpm) in the study area. High $\mathrm{CO}_{2}$ is likely from soil production from heterotrophic oxidation of soil organic matter and respiration from plant roots (Doctor and others, 2008). Therefore, groundwater from well DW-17 exhibits characteristics of rapid recharge. Groundwater at DW-5A has moderate $\mathrm{CO}_{2}$ concentrations and, therefore, its relatively low $\delta^{13} \mathrm{C}$ value (section 4.2) is attributed to less contact time with calcite minerals. Groundwater at $\mathrm{MW}-30$ had low $\mathrm{CO}_{2}$ concentrations indicating little rapid recharge.

Argon (Ar) is a noble gas and its exchange with the atmosphere ceases when water enters the saturated zone (Manning, 2009). Noble gases are chemically inert and their concentrations seldom change along flowpaths. This condition allows for the use of dissolved noble gases as a marker on the time and location of recharge water as it enters the saturated zone by the ability to use this information to calculate a recharge temperature (RT) of the water as it enters the saturated zone.

Calculated RT was made from an analysis of dissolved nitrogen and argon for an assumed amount of excess nitrogen corresponding to the pressure associated with the elevation of the land surface of the well (Heaton and Vogel, 1981). Recharge temperatures ranged from $4.1^{\circ} \mathrm{C}(\mathrm{DW}-25)$ to $8.1^{\circ} \mathrm{C}$ (DW-5A). Warmer RT indicates rapid recharge of groundwater given the time of the sampling was August 2011. Recharge temperatures compare favorably to the inverse of the $\delta^{13} \mathrm{C}$ for most wells except DW-25 and MW-30 (fig. 6). This suggests that soil $\mathrm{CO}_{2}$ is an important factor in $\delta^{13} \mathrm{C}$ value because warm RT is indicative of summer recharge. A linear regression of RT and $\delta^{13} \mathrm{C}$ excluding DW25 and MW-30 yields a coefficient of determination $\left(\mathrm{R}^{2}\right)$ of 0.78 (fig. $6 \mathrm{~B}$ ).

Calculated RT also compared favorably to the inverse of excess air in the samples. Excess air in the samples occurs when air is entrapped in groundwater during recharge. Excess air is commonly associated with large water-table fluctuations that occur in cold months. A linear regression of RT and excess air yields an $\mathrm{R}^{2}$ of 0.67 . 
Table 5. Results of dissolved gas in groundwater from monitoring and residential wells, Savage Municipal Well Superfund site, Milford, New Hampshire.

[Residential wells start with the prefix DW. Monitoring wells include BR-3, BR-4, and MW-30. All values are in milligrams per liter. Ar, argon; $\mathrm{CH}_{4}$, methane; $\mathrm{CO}_{2}$, carbon dioxide; $\mathrm{N}_{2}$, nitrogen; $\mathrm{O}_{2}$, oxygen]

\begin{tabular}{|c|c|c|c|c|c|c|c|c|c|c|}
\hline \multirow[b]{2}{*}{ Well $^{1}$} & \multicolumn{2}{|c|}{$\mathrm{N}_{2}$} & \multicolumn{2}{|c|}{$\mathrm{Ar}$} & \multicolumn{2}{|c|}{$\mathrm{O}_{2}$} & \multicolumn{2}{|c|}{$\mathrm{CO}_{2}$} & \multicolumn{2}{|c|}{$\mathrm{CH}_{4}$} \\
\hline & Mean & $\begin{array}{l}\text { Standard } \\
\text { deviation }\end{array}$ & Mean & $\begin{array}{l}\text { Standard } \\
\text { deviation }\end{array}$ & Mean & $\begin{array}{l}\text { Standard } \\
\text { deviation }\end{array}$ & Mean & $\begin{array}{l}\text { Standard } \\
\text { deviation }\end{array}$ & Mean & $\begin{array}{l}\text { Standard } \\
\text { deviation }\end{array}$ \\
\hline DW-17 & 26.59534 & 0.03695 & 0.87786 & 0.00070 & 0.31707 & 0.00438 & 10.48209 & 0.04336 & 0.00176 & 0.00011 \\
\hline DW-24 & 24.28567 & 0.00060 & 0.83696 & 0.00252 & 0.31245 & 0.00097 & 2.26717 & 0.04404 & 0.00740 & 0.00071 \\
\hline DW-9A & 22.76611 & 0.12992 & 0.80666 & 0.00493 & 0.29447 & 0.00281 & 1.17167 & 0.00118 & 0.00000 & 0.00000 \\
\hline DW-25 & 25.48657 & 0.00506 & 0.86978 & 0.00085 & 0.31288 & 0.00278 & 1.07636 & 0.01047 & 0.00000 & 0.00000 \\
\hline DW-5A & 24.32725 & 0.14455 & 0.80747 & 0.00156 & 0.28880 & 0.00208 & 1.45724 & 0.04280 & 0.00074 & 0.00020 \\
\hline DW-6 & 28.03265 & 0.16318 & 0.91068 & 0.00134 & 0.32293 & 0.00963 & 1.39997 & 0.00132 & 0.00168 & 0.00137 \\
\hline DW-2 & 24.14230 & 0.08934 & 0.83316 & 0.00301 & 0.35770 & 0.06237 & 1.16506 & 0.12831 & 0.00126 & 0.00012 \\
\hline DW-12 & 22.83133 & 0.02529 & 0.80949 & 0.00222 & 0.29972 & 0.01513 & 2.47624 & 0.02459 & 0.00000 & 0.00000 \\
\hline DW-29 & 22.94571 & 0.15744 & 0.80671 & 0.00289 & 0.55386 & 0.17658 & 0.87365 & 0.04255 & 0.00000 & 0.00000 \\
\hline BR-4 & 23.95804 & 0.07792 & 0.82741 & 0.00151 & 0.31607 & 0.00566 & 0.49936 & 0.01635 & 0.00000 & 0.00000 \\
\hline MW-30 & 19.62685 & 0.09213 & 0.73480 & 0.00405 & 0.28182 & 0.01016 & 0.03532 & 0.02207 & 2.94754 & 0.09149 \\
\hline BR-3 & 24.18718 & 0.02744 & 0.82770 & 0.00044 & 0.30076 & 0.01133 & 1.00889 & 0.02519 & 0.00589 & 0.00013 \\
\hline
\end{tabular}

${ }^{1}$ Location of wells shown in figure 1. 


\section{Implications for PCE Transport}

Results of the geochemical, isotopic, and dissolved gas analyses can be used to characterize the residential wells based on their potential for capturing groundwater that has traveled along long flowpaths ( $>1 / 4$ mile). Long flowpaths are considered necessary to transport PCE contamination from PCE source areas to the area served by the residential wells. Conversely, short flowpaths are less likely to transport PCE contamination to the residential wells given the distances between the residential wells and PCE contamination (fig. 1). A preponderance of recharge to wells from short flowpaths augments the need for wells to capture long flowpaths that potentially could be transporting PCE.

The geochemical, isotopic, and dissolved gas analyses provide information on contact time between the groundwater and the rock. The information on contact time is then used to infer flowpath length assuming that (1) contact time is analogous to travel time, and (2) travel time generally increases with increasing flowpath length. It is acknowledged that heterogeneity affects the mineralogy and permeability distribution of the fractured-rock aquifer and that contact time may not be precisely analogous to travel time or flowpath length. However, as a "rule of thumb" it is believed that there is a general overall positive relation between increasing contact time and flowpath length.

Individually and collectively, the chemical analyses can be used as a semiquantitative guide in determining flowpath length. The chemistry data are also potentially useful in identifying the amount of mixing in the open borehole. Potentially highly mixed groundwater in the residential wells likely means a greater ability to dilute contaminants if a limited subset of fractures transports PCE.

\subsection{Vulnerability Rank Model}

Different categories of chemical analyses are affected by different reactions or conditions. The synthesis of results can be used to develop multiple lines of evidence to identify flowpath length. Several categories of chemical analyses were used to rank the samples based on the potential of the well to capture water that had traveled along short or long flowpaths (table 6). The criteria for ranking are specified in table 6 under the predominant process for that particular analysis. For example, light isotopic $\delta^{13} \mathrm{C}$ values are interpreted as groundwater with little contact with carbonate minerals and/or recharged rapidly from shallow sources such as groundwater showing the effect of soil gas $\mathrm{CO}_{2}$. Therefore for $\delta^{13} \mathrm{C}$, wells were ranked from light to heavy. Heavier $\delta^{13} \mathrm{C}$ values would imply that the groundwater traveled along longer flowpaths. Wells more likely to intercept long flowpaths were identified under each category as those falling in the lower half (arbitrary limit) of the ranking (ranking from short to long).

The ranking for $\delta \mathrm{D}$ and $\delta^{18} \mathrm{O}$ is more complex and relates to the relative effect of seasonal vs. long-term recharge. Groundwater samples with either light or heavy "end member" $\delta \mathrm{D}$ and $\delta^{18} \mathrm{O}$ values were considered affected by seasonal recharge and ranked under the short flowpath category. Groundwater samples with intermediate $\delta \mathrm{D}$ and $\delta^{18} \mathrm{O}$ values were considered representative of diffuse, average recharge and ranked under the long flowpath category. Alternatively, bimodal mixing of end member $\delta \mathrm{D}$ and $\delta^{18} \mathrm{O}$ values from multiple water-bearing fractures could produce similar intermediate $\delta \mathrm{D}$ and $\delta^{18} \mathrm{O}$ values. In this case, the samples ranked in other categories would provide some insight on the amount of mixing in the well.

By simply counting the number of times a well falls into the lower half of each category, a relative assessment can be made of a well's vulnerability to capture long flowpaths. Of the nine wells that were sampled for chemistry, isotopes, and dissolved gases, wells DW-2, DW-24, DW-17, and DW-6 ranked in the lower half three times and had the highest occurrences in the lower half (relative score). Therefore these four wells likely capture some groundwater from long flowpaths. Wells DW-29, 
DW-25, and DW-9A ranked in the lower half twice and have groundwater chemical signatures that suggest possible capture of long flowpaths.

Several wells show strong characteristics of having mixed groundwater and likely capture groundwater from a variety of shallow and deep fractures. These include DW-17 (high $\mathrm{CO}_{2}$, moderate $\delta^{13} \mathrm{C}$ value, moderate cation exchange (major ion), and colder RT), and DW-5A (relatively heavy $\delta \mathrm{D}$ and $\delta^{18} \mathrm{O}$ values but major ions indicate cation exchange). At DW-5A, the heavy $\delta \mathrm{D}$ and $\delta^{18} \mathrm{O}$ values indicate groundwater is affected by evapotranspiration during the summer; groundwater recharged primarily in summer months is interpreted as recent recharge. Conversely, DW-5A also has evidence of being affected by cation exchange, which is characterized as a more chemically mature water type. This vulnerability assessment is based on a model to evaluate flowpath length but should be tempered by the location of the well relative to the PCE contamination source. For example, although wells DW-24 and DW-25 show evidence of capturing long flowpaths, their location indicates that they receive a part of their recharge from the hillside areas to the west. Conversely, a high level of vulnerability may be appropriate for well DW-2, which is near the PCE contamination and has evidence of capturing long flowpaths (relative score of three). The flowpath length model should also be tempered by the potential for mixing of young and old groundwater in a well indicating the ability to dilute contaminants being transported by select fractures. 
Table 6. Ranking of groundwater samples from wells based on results of chemical analyses and the potential of capturing long flowpaths, Savage Municipal Well Superfund site, Milford, New Hampshire.

[Monitoring wells excluding (BR-3, BR-4, and MW-30). $\delta^{13} \mathrm{C}$, del value of dissolved inorganic carbon of carbon-13 isotope; RT, recharge temperature; $\mathrm{CO}_{2}$, carbon dioxide; $\delta \mathrm{D}$, deuterium; $\delta^{18} \mathrm{O}$, oxygen-18. Shaded cells are wells more likely to capture long flowpaths; Arrow indicates direction of increasing flowpath length].

\begin{tabular}{|c|c|c|c|c|c|}
\hline Category & Major ion & $\delta^{13} \mathrm{C}$ & $\mathrm{CO}_{2}$ & RT & $\delta D$ and $\delta^{18} O$ \\
\hline $\begin{array}{l}\text { Predominant process } \\
\text { used for the ranking } \\
\text { of vulnerability }\end{array}$ & $\begin{array}{l}\text { Cation exchange } \\
\text { (chemical maturity) }\end{array}$ & $\begin{array}{l}\text { Carbonate (for example, } \\
\text { calcite) dissolution and } \\
\mathrm{CO}_{2} \text { soil gas input }\end{array}$ & $\begin{array}{l}\mathrm{CO}_{2} \text { soil gas and shallow } \\
\text { recharge }\end{array}$ & $\begin{array}{l}\text { Seasonal (summer and winter) } \\
\text { recharge }\end{array}$ & $\begin{array}{l}\text { Fractionation from seasonal } \\
\text { recharge }\end{array}$ \\
\hline Ranking order & $\begin{array}{l}\text { Low (short flowpath) to } \\
\text { high (long flowpath) } \mathrm{Na} \\
\text { to Ca milliequivalent } \\
\text { per liter ratio }\end{array}$ & $\begin{array}{l}\text { Light (short flowpath) to } \\
\text { heavy (long flowpath) } \\
\text { isotopic composition }\end{array}$ & $\begin{array}{l}\text { High (short flowpath) to } \\
\text { low (long flowpath) } \\
\text { concentrations }\end{array}$ & $\begin{array}{l}\text { Warmer or colder RT (short } \\
\text { flowpaths ) to average RT } \\
\text { (long flowpaths,and diffuse } \\
\text { recharge) }\end{array}$ & $\begin{array}{l}\text { Heavy or light (short flowpaths) } \\
\text { to intermediate (long flowpath) } \\
\text { isotopic composition }\end{array}$ \\
\hline Short flowpaths & $\begin{array}{l}\text { DW-28* } \\
\text { DW-25 } \\
\text { DW-23* } \\
\text { DW-22* } \\
\text { DW-29 } \\
\text { DW-24 } \\
\text { DW-17 } \\
\text { DW-30* } \\
\text { DW-27* }\end{array}$ & $\begin{array}{l}\text { DW-5A } \\
\text { DW-25 } \\
\text { DW-9A } \\
\text { DW-2 } \\
\text { DW-12 }\end{array}$ & $\begin{array}{l}\text { DW-17 } \\
\text { DW-12 } \\
\text { DW-24 } \\
\text { DW-5A } \\
\text { DW-6 }\end{array}$ & $\begin{array}{l}\text { DW-5A } \\
\text { DW-29 } \\
\text { DW-9A } \\
\text { DW-12 } \\
\text { DW-2 }\end{array}$ & $\begin{array}{l}\text { DW-5A } \\
\text { DW-6 } \\
\text { DW-9A } \\
\text { DW-12 } \\
\text { DW-29 }\end{array}$ \\
\hline 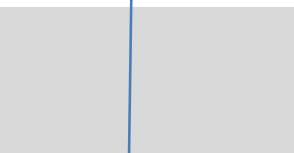 & $\begin{array}{l}\text { DW-12 } \\
\text { DW-20* } \\
\text { DW-5A } \\
\text { DW-6 }\end{array}$ & $\begin{array}{l}\text { DW-17 } \\
\text { DW-24 } \\
* * \text { DW-29 } \\
\text { DW-6 }\end{array}$ & $\begin{array}{l}\text { DW-9A } \\
\text { DW-2 } \\
\text { DW-25 } \\
\text { DW-29 }\end{array}$ & $\begin{array}{l}\text { DW-24 } \\
\text { DW-17 } \\
\text { DW-6 } \\
\text { DW-25 }\end{array}$ & $\begin{array}{l}\text { DW-17 } \\
\text { DW-25 } \\
\text { DW-2 } \\
\text { DW-24 }\end{array}$ \\
\hline Long flowpaths & $\begin{array}{l}\text { DW-2 } \\
\text { DW-21* } \\
\text { DW-19* } \\
\text { DW-18* } \\
\text { DW-9A }\end{array}$ & & & & \\
\hline
\end{tabular}

*Sample for major ion data only.

**Heavier $\delta^{13} \mathrm{C}$ but low alkalinity suggests mixing. 


\section{Conclusions}

Understanding the origin of groundwater flow to fractured-rock aquifers provides a mechanism to assess the vulnerability of residential-supply wells to capture contaminants from known contamination areas. For this study, although concentrations of tetrachloroethylene (PCE) have yet to be detected in samples from nearby residential-supply wells, concerns over future changes in hydraulic stresses (pumpage) or modifications to remedial operations at operable units provided motivation to characterize groundwater from the residential-supply wells. The interpretation of geochemical and isotopic data helped researchers assess the origin of flowpaths to each well.

Groundwater samples that were collected from monitoring and residential-supply wells represent an integrated sample from multiple flowpaths and multiple fractures. Deciphering the likely origin of groundwater from each well sample required the use of multiple lines of evidence, which were provided by the suite of chemical, isotopic, and dissolved gas analyses performed for this study.

A simple vulnerability-rank model was developed that utilized the multiple lines of evidence approach based on data collected for this study. The vulnerability-rank model assumes that groundwater that appears to be younger is recharged by short flowpaths. Short flowpaths originate closer to the well. Given the distances ( $>1 / 4$ mile) of some of the residential-supply wells to areas of known contamination, wells characterized as containing signatures of young groundwater are assumed to be less at risk. Groundwater samples that exhibit a high level of mixing of younger and older waters are from wells that have the capability of diluting contaminants because they capture a variety of flowpaths. Groundwater that appears to be older is assumed to be recharged by long flowpaths $(>1 / 4$ mile). Long flowpaths are capable of transporting contaminants to residential-supply wells. Four wells were characterized as containing signatures of old groundwater. Two of the four wells are closer to PCE source areas and may be the most vulnerable to potential PCE contamination; these wells could be targeted for additional study to understand their fracture and flow characteristics.

Results of this work can be used to help target wells for additional chemical analyses and geophysical investigations. For example, age dating of groundwater samples with environmental tracers would refine the evaluation of flowpath length. Geophysical logging can be performed to help map fracture patterns in open boreholes and help track sources of water. Sampling of both open boreholes (this study) and discrete fractures would help researchers identify the relative contribution of fractures to the integrated open-borehole sample. Collectively, the estimates of age from groundwater samples and geophysical fracture mapping would provide additional evidence to evaluate vulnerability of residential wells to capture PCE contaminants. The vulnerability-rank model of categorical data developed by this study is most appropriate as a screening tool for followup investigations.

\section{References Cited}

Benjamin, Lyn, Knobel, L.L., Hall, L.F., Cecil, L.D., and Green, J.R., 2004, Development of a local meteoric water line for southeastern Idaho, western Wyoming, and south-central Montana: U.S. Geological Survey Scientific Investigations Report 2004-5126, 17 p. (Also available at http://pubs.usgs.gov/sir/2004/5126/.)

Bullen, T.D., and Kendall, Carol, 1998, Tracing of weathering reactions and water flowpaths-A multiisotope approach, in Kendall, Carol, and McDonnell, J.J. eds., Isotope tracers in catchment hydrology: Amsterdam, Elsevier, p. 611-646.

Busenberg, Eurybiades, Plummer, L.N., Bartholomay, R.C., and Wayland, J.E., 1998, Chlorofluorocarbons, sulfur hexafluoride, and dissolved permanent gases in groundwater from 
selected sites in and near the Idaho National Engineering and Environmental Laboratory, Idaho, 1994-97: U.S. Geological Survey Open-File Report 98-274, 72 p.

Clark, S.F., Jr., Ferguson, E.W., Picard, M.Z., and Moore, R.B., 1997, Lineament map of area 2 of the New Hampshire bedrock aquifer assessment, south-central New Hampshire: U.S. Geological Survey Open-File Report 96-490, 1 sheet, scale 1:48,000.

Craig, Harmon, 1961, Isotopic variations in meteoric waters: Science, v. 133, p. 1702-1703.

Coplen, T.B., Wildman, J.D., and Chen, J., 1991, Improvements in the gaseous hydrogen-water equilibration technique for hydrogen isotope ratio analysis: Analytical Chemistry, v. 63, p. 910-912.

Doctor, D.H., Kendall, Carol, Sebestyen, S.D., Shanley, J.B., Ohte, Nobuhito, and Boyer, E.W., 2008, Carbon isotope fractionation of dissolved inorganic carbon (DIC) due to outgassing of carbon dioxide from a headwater stream: Hydrological Processes, v. 22, p. 2410-2423.

Epstein, S., and Mayeda, T., 1953, Variation of O-18 content of water from natural sources: Geochimica et Cosmochimica Acta, v. 4, p. 213-224.

Flanagan, S.M., Ayotte, J.D., and Robinson, G.R., Jr., 2012, Quality of water from crystalline rock aquifers in New England, New Jersey, and New York, 1995-2007: U.S. Geological Survey Scientific Investigations Report 2011-5220, 104 p. (Also available at http://pubs.usgs.gov/sir/2011/5220.)

Harte, P.T., 2004, Simulation of source transport of tetrachloroethylene in ground water of the glacialdrift aquifer at the Savage municipal well superfund site, Milford, New Hampshire, 1960-2000: U.S. Geological Survey Scientific Investigations Report 2004-5176, 78 p.

Harte, P.T., 2006, Effects of a remedial system and its operation on volatile organic compoundcontaminated ground water, operable unit 1, Savage municipal well superfund site, Milford, New Hampshire, 1998-2004: U.S. Geological Survey Scientific Investigations Report 2006-5083, 80 p. Harte, P.T., Ayotte, J.D., Hoffman, Andrew, Rèvèsz, K.M., Beleval, Marcel, Lamb, Steven, and Böhlke, J.K., 2012, Heterogeneous redox conditions, arsenic mobility, and groundwater flow in a fracturedrock aquifer near a waste repository site in New Hampshire, USA: Hydrogeology Journal, v. 20 , no. 6, p. 1189-1201, doi:10.1007/s10040-012-0844-4.

Harte, P.T., Robinson, G.R., Jr., Ayotte, J.D., and Flanagan, S.M., 2008, Framework for evaluating water quality of the New England crystalline rock aquifers: U.S. Geological Survey Open-File Report 2008-1282, 47 p. (Also available at http://pubs.usgs.gov/ofr/2008/1282.)

Heaton, T.H.E., and Vogel, J.C., 1981, “Excess air” in groundwater: Journal of Hydrology, v. 50, p. 201-216.

Kendall, Carol, and Coplen, T.B., 2000, Distribution of oxygen-18 and deuterium in river waters across the United States: Hydrological Processes, v. 15, p. 1363-1393.

Kendall, Carol, Sklash, M.G., and Bullen, T.D., 1995, Isotope tracers of water and solute sources in catchments, in Trudgill, S.T., ed., Solute modeling in catchment systems: New York, John Wiley and Sons, p. 261-303.

Lipfert, Gail, and Reeve, A.S., 2004, Characterization of three water types in a fractured schist, high arsenic, watershed in Maine: 2004 U.S. Environmental Protection Agency/National Ground Water Association Fractured Rock Conference, Portland, Maine; accessed October, 15, 2012 at http://cluin.org/products/siteprof/2004fracrock.conf/cdr_pdfs/indexed/group1/638.pdf.

Lipfert, Gail, Reeve, A.S., Sidle, W.C., and Marvinney, R., 2006, Geochemical patterns of arsenicenriched ground water in fractured, crystalline bedrock, Northport, Maine: Applied Geochemistry, v. 21 , no. 3, p. 528-545.

Lyons, J.B., Bothner, W.A., Moench, R.H., and Thompson, J.B., Jr., 1997, Bedrock geologic map of New Hampshire: U.S. Geological Survey, scale 1:250,000. 
Mabee, S.B., and Hardcastle, K.C., 1997, Analyzing outcrop-scale fracture features to supplement investigations of bedrock aquifers: Hydrogeology Journal, v. 5, no. 4, p. 21-36.

Manning, A.H., 2009, Ground-water temperature, noble gas, and carbon isotope data from the Española Basin, New Mexico: U.S. Geological Survey Scientific Investigations Report 2008-5200, 69 p.

Mills, A.L., 1988, Variations in the $\mathrm{dC}-13$ of stream bicarbonate-Implications for sources of alkalinity: Washington, D.C., George Washington University master's thesis, 160 p.

New Hampshire Department of Transportation, 2005, NH GRANIT 2005 1-FT color aerial photos, southeast NH: Concord, N.H., New Hampshire Department of Transportation. (Also available at http://www.granit.unh.edu/data/downloadfreedata/alphabetical/databyalpha.html.)

New Hampshire Department of Environmental Services, 2011, Sampling and analysis plan (SOP) Savage municipal water supply superfund site OU-3, 621 Elm Street Milford, N.H.: Concord, N.H., Weston Solutions, Inc.

New Hampshire Department of Environmental Services, [undated], Savage municipal water supply well: New Hampshire Department of Environmental Services, accessed October 15, 2012, at http://des.nh.gov/organization/divisions/waste/hwrb/fss/superfund/summaries/savage.htm.

Piper, A.M., 1944, A graphical procedure in the geochemical interpretation of water analyses: Transactions, American Geophysical Union, v. 25, p. 914-923.

Révész, Kinga, and Coplen, T.B., 2008a, Determination of the delta $\left({ }^{2} \mathrm{H} /{ }^{1} \mathrm{H}\right)$ of water: RSIL lab code 1574, in Révész, Kinga, and Coplen, T.B., eds., Methods of the Reston Stable Isotope Laboratory: U.S. Geological Survey Techniques and Methods, book 10, chap.C1, 27 p. (Also available at http://pubs.water.usgs.gov/tm10C1/.)

Révész, Kinga, and Coplen, T.B., 2008b, Determination of the delta $\left({ }^{18} \mathrm{O} /{ }^{16} \mathrm{O}\right)$ of water: RSIL lab code 489, in Révész, Kinga, and Coplen, Tyler B., eds., Methods of the Reston Stable Isotope Laboratory: U.S. Geological Survey Techniques and Methods, book 10, chap. C2, 28 p. (Also available at http://pubs.water.usgs.gov/tm10C2/.)

St-Jean, G., 2003, Automated quantitative and isotopic $\left({ }^{13} \mathrm{C}\right)$ analysis of dissolved inorganic carbon and dissolved organic carbon in continuous-flow using a total organic carbon analyser: Rapid Communication in Mass Spectrometry, v. 17, no. 5, p. 419-428.

U.S. Geological Survey, 2012a, Reston Dissolved Gas Laboratory: U.S. Geological Survey, accessed January 31, 2012, at http://water.usgs.gov/lab/.

U.S. Geological Survey, 2012b, Reston Stable Isotope Laboratory: U.S. Geological Survey, accessed January 31, 2012, at http://isotopes.usgs.gov/.

Weston, Inc., 2009, Draft 2009 annual report-Savage municipal well superfund site, Milford, New Hampshire: Concord, N.H., Weston Solutions, Inc.

Weston, Inc., 2010, Draft bedrock investigation and conceptual site model report Savage municipal water supply superfund site OU-1, 621 Elm Street, Milford, New Hampshire: Concord, N.H., Weston Solutions, Inc.

Weston, Inc., 2012, Draft technical memo on bedrock investigations at the Savage municipal water supply superfund site OU-1, 621 Elm Street, Milford, New Hampshire: Concord, N.H., Weston Solutions, Inc., Weston Solutions, Inc. 
Figures 


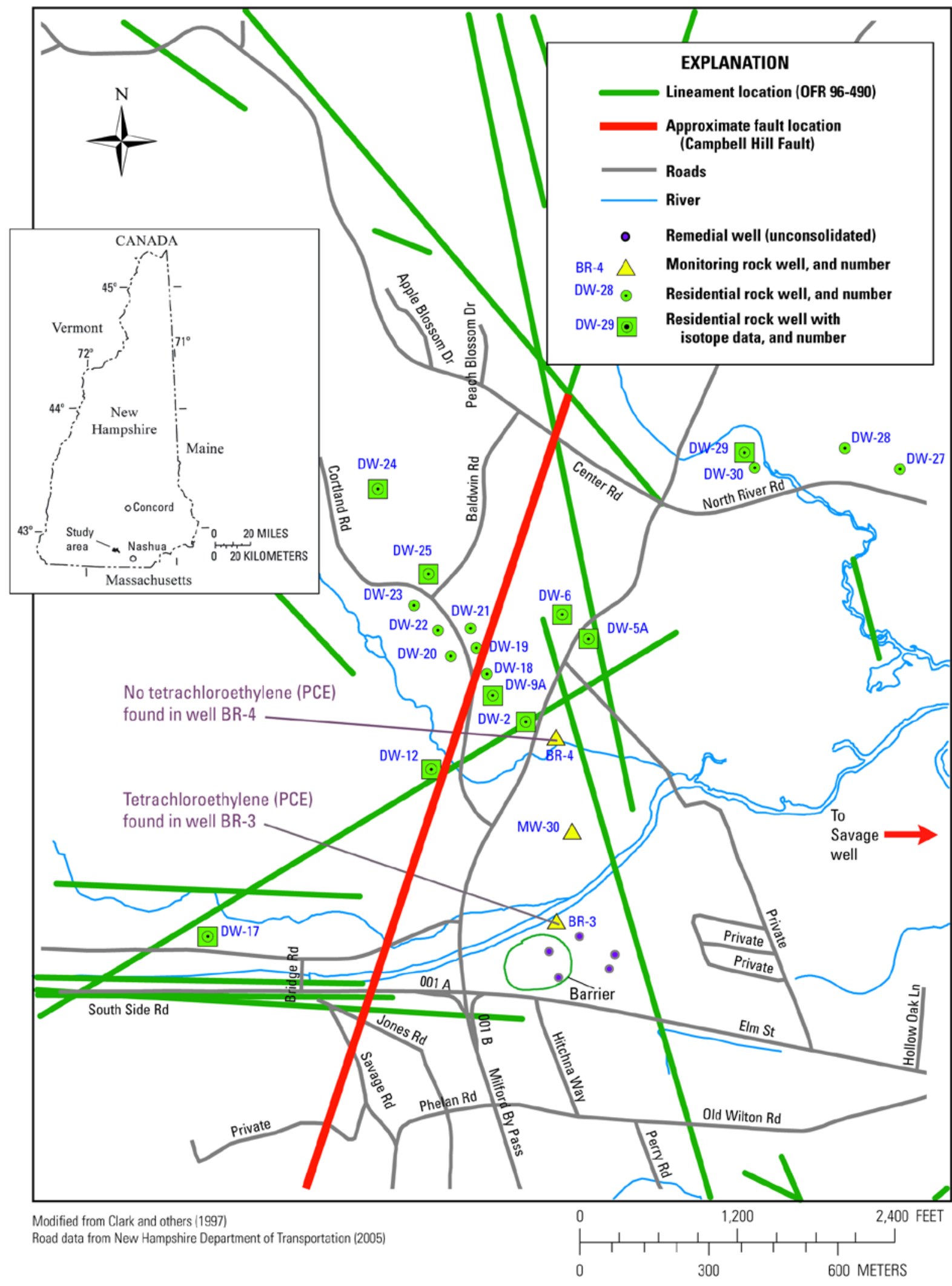

Figure 1. Location map of monitoring wells and residential-supply wells, Savage Municipal Well Superfund site, Milford, New Hampshire. 


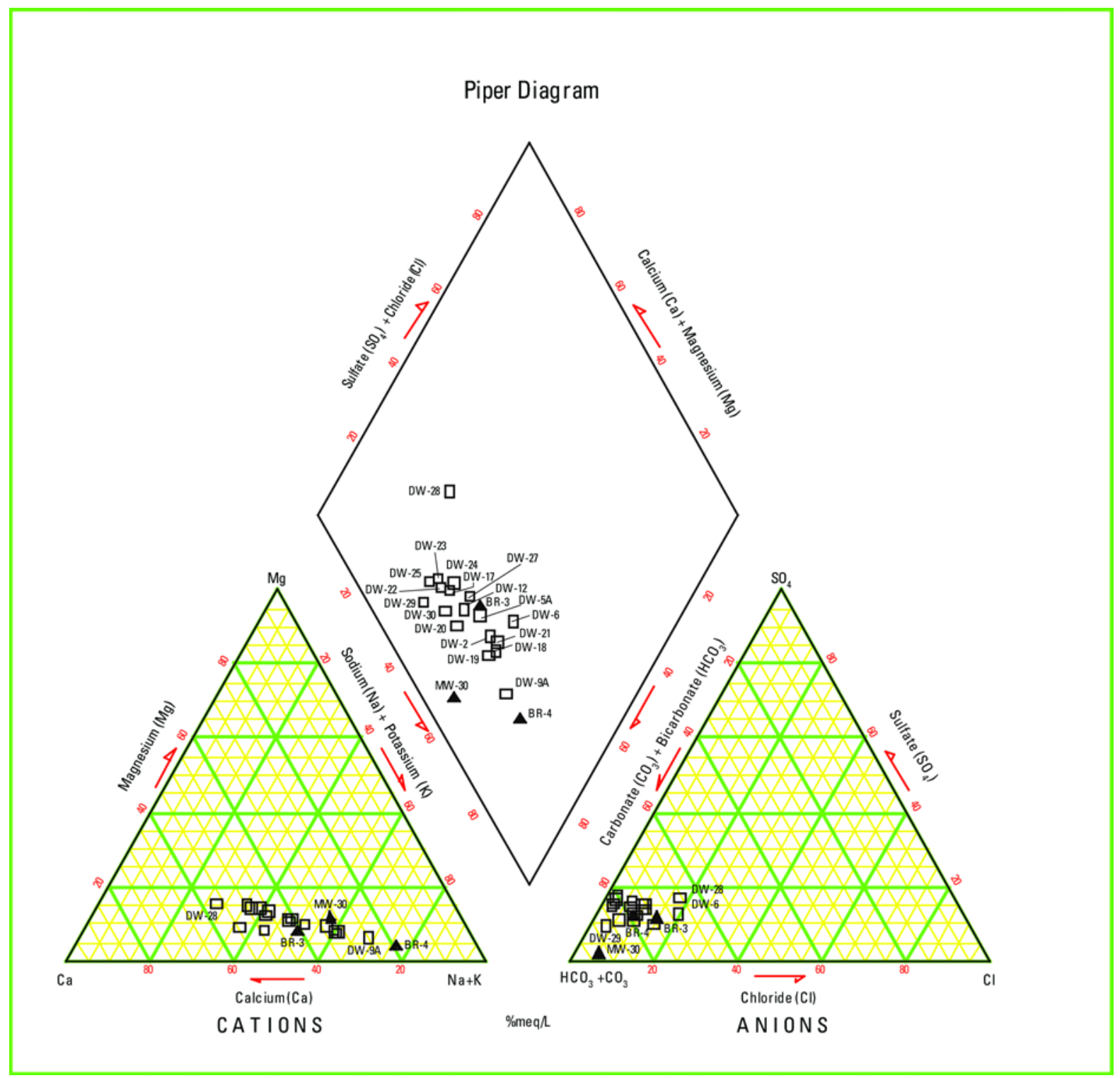

Figure 2. Piper diagram of major water type for residential and monitoring wells, Savage Municipal Well Superfund site, Milford, New Hampshire. \%meq/L, percent milliequivalents per liter. Residential wells start with the prefix DW; monitoring wells include BR-3, BR-4, and MW-30. 

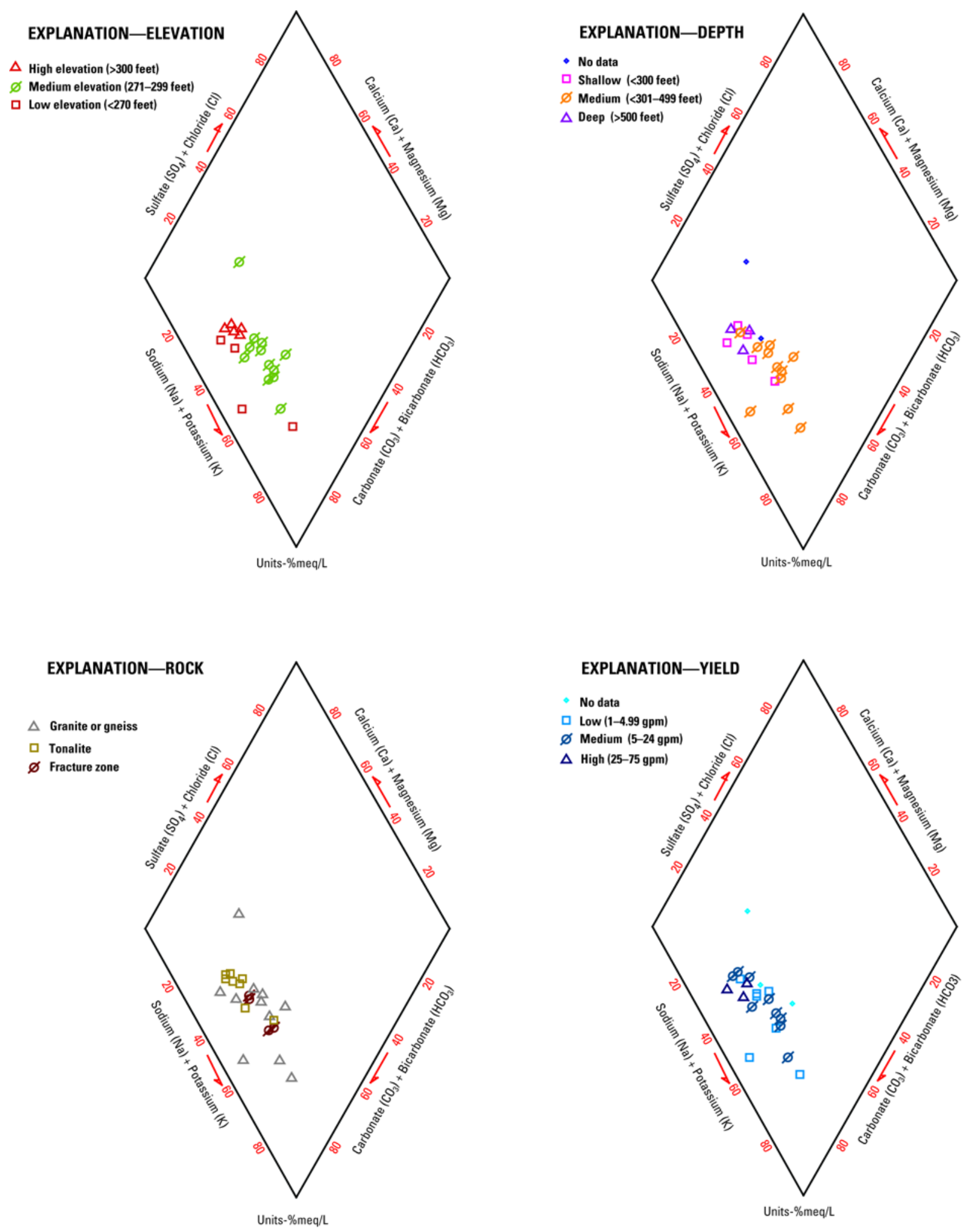

Figure 3. Modified piper of major water type (showing combined cation-anion plot only) for residential and monitoring wells, classified by well parameter, Savage Municipal Well Superfund site, Milford, New Hampshire. $\%$ meq/L, percent milliequivalents per liter; gpm, gallons per minute. 

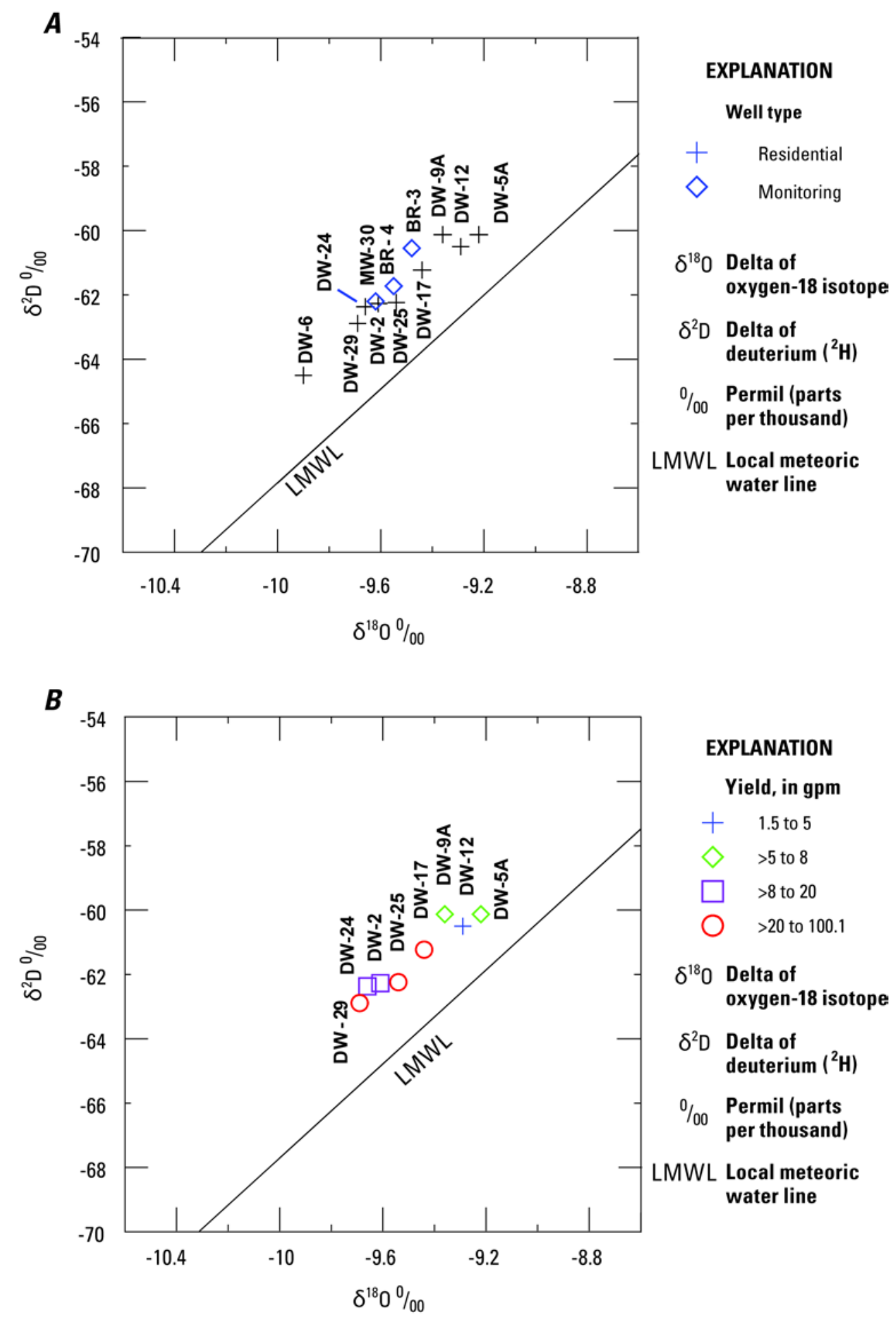

Figure 4. Graphs showing relation of stable isotopes of $\delta \mathrm{D}$ and $\delta^{18} \mathrm{O}$ of groundwater from residential and monitoring well samples and the local meteoric water line (LMWL) by $A$, well type and $B$, yield, Savage Superfund site, Milford, New Hampshire. gpm, gallons per minute. 


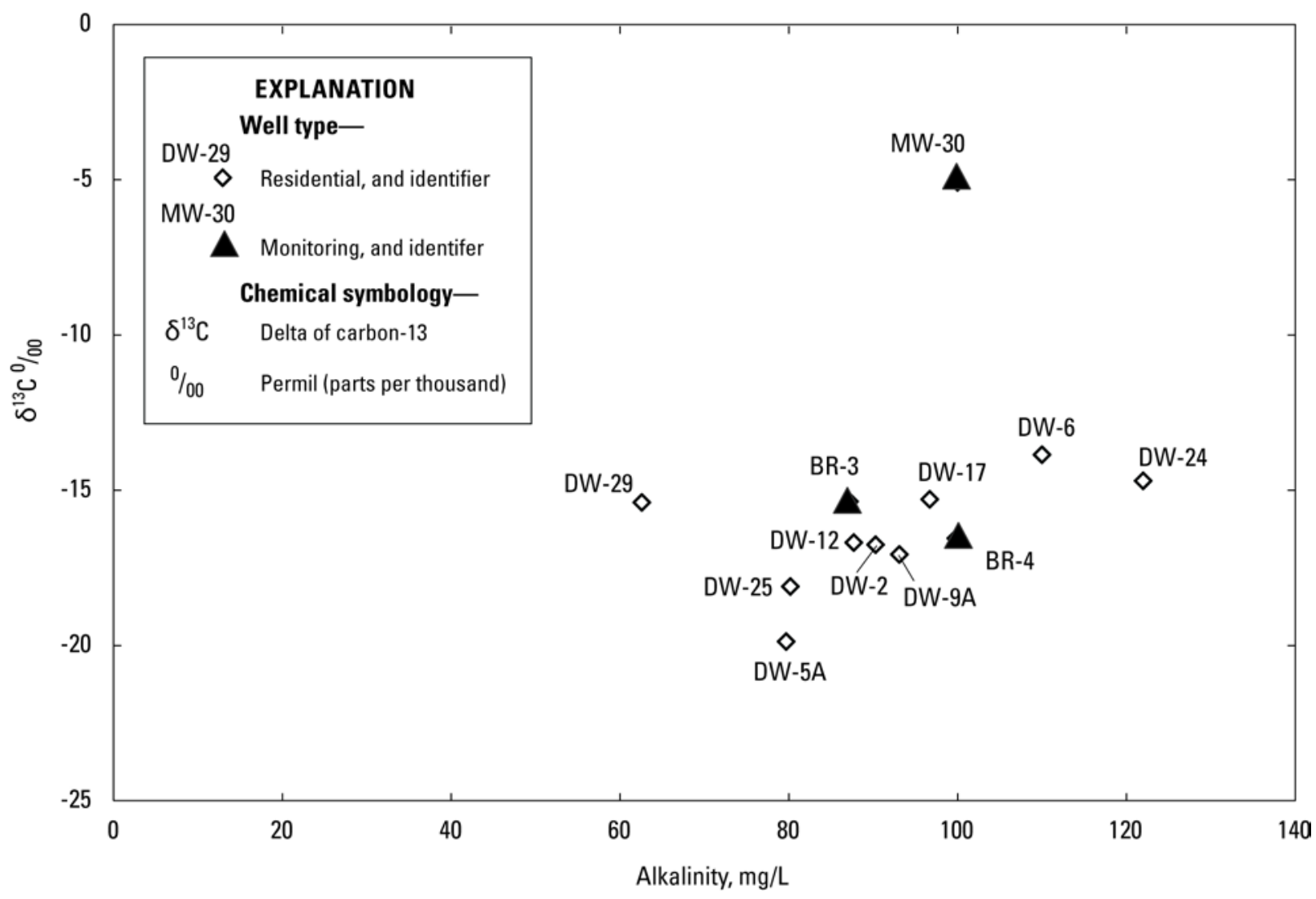

Figure 5. Graph showing relation of the delta of carbon-13 isotope $\left(\delta^{13} \mathrm{C}\right)$ and alkalinity of groundwater from residential and monitoring well samples, Savage Municipal Well Superfund site, Milford, New Hampshire. 
A. All wells

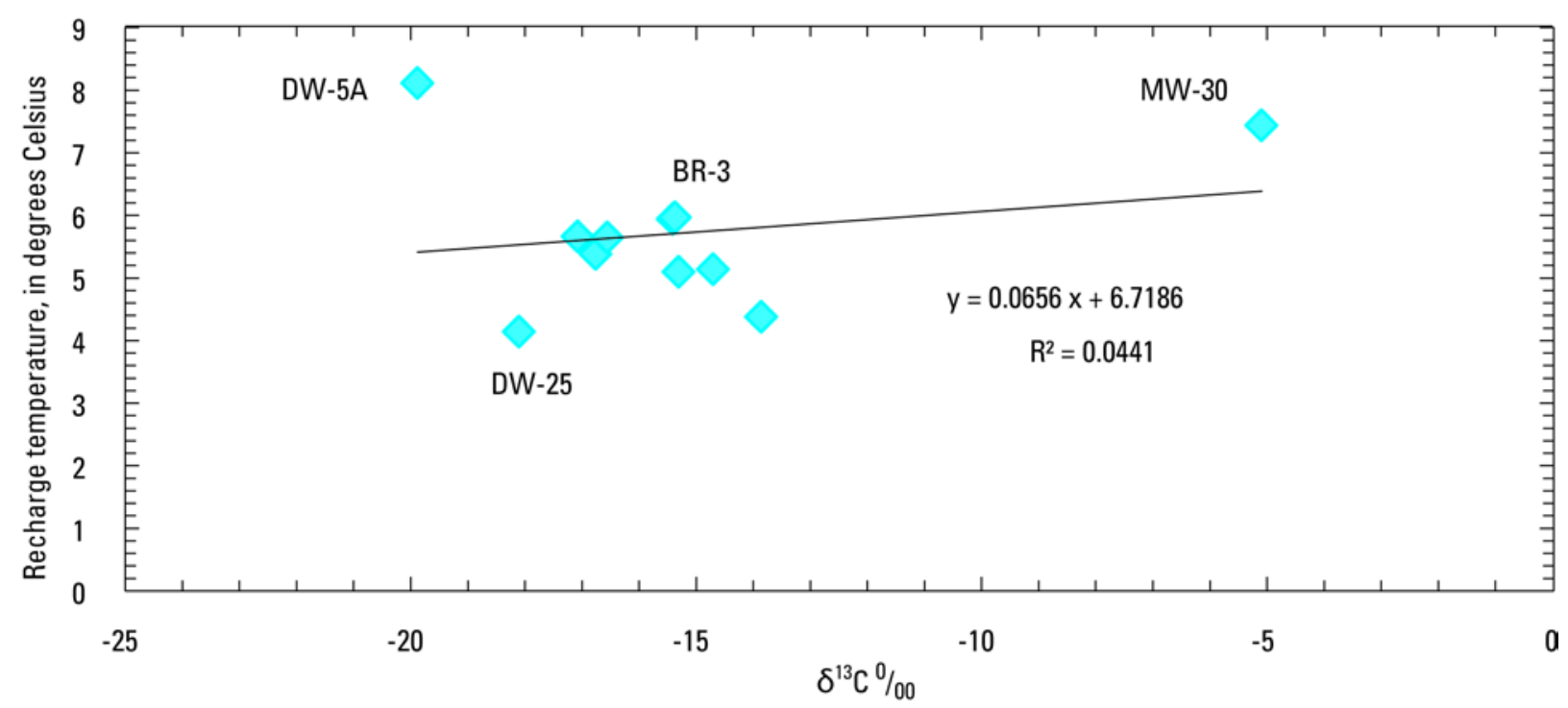

B. Exclude DW-25, MW-30

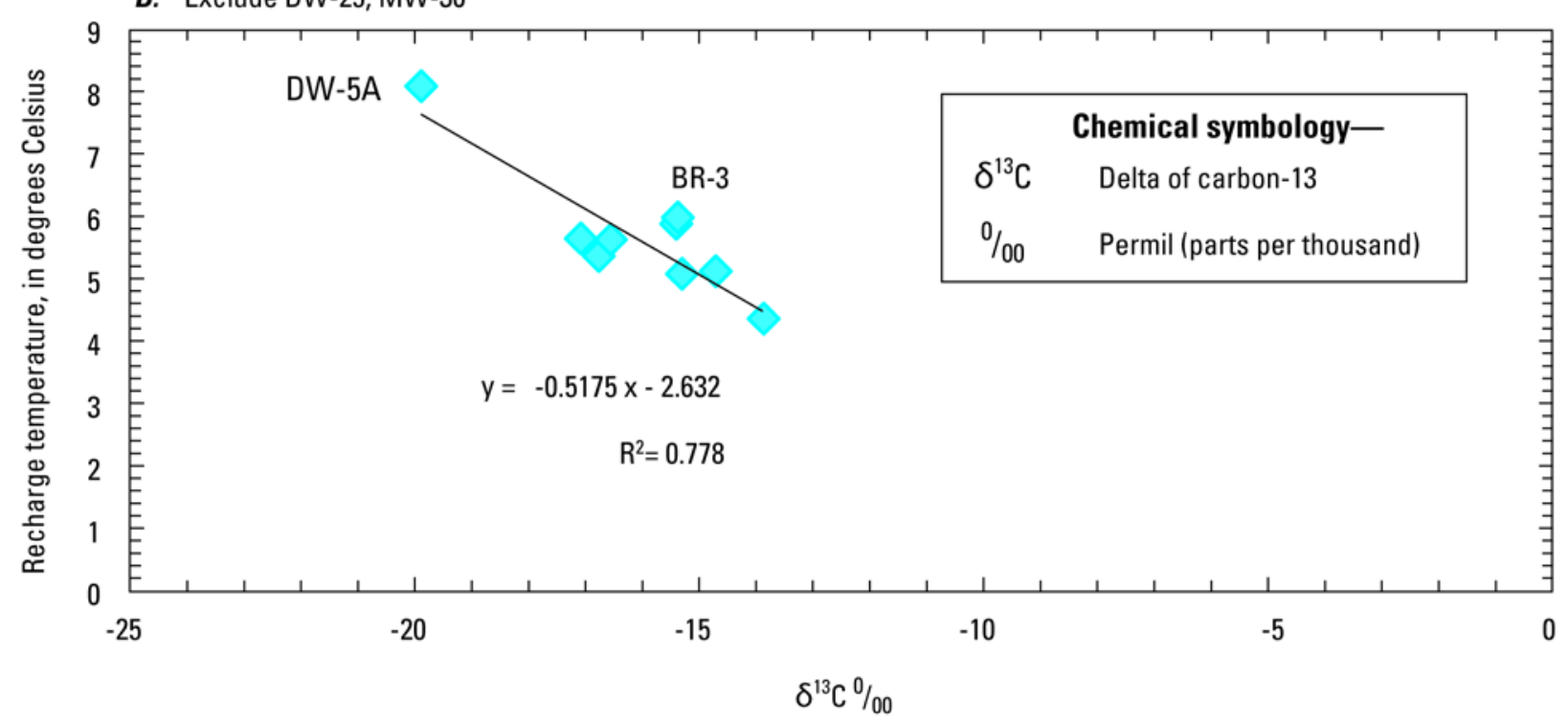

Figure 6. Graphs showing relation of recharge temperature from argon-nitrogen gas and $\delta^{13} C$ of groundwater from residential and monitoring well samples for $A$, all wells and $B$, selected wells, Savage Municipal Well Superfund site, Milford, New Hampshire. $R^{2}$, coefficient of determination. 


\section{Appendix 1. Wells Sampled for Analysis of Isotopes}

Table 1-1. New Hampshire Department of Environmental Services and U.S. Geological Survey site identifiers for sampled wells analyzed for isotopes, OU3 Savage Municipal Well Superfund site, Milford, New Hampshire. [NHDES, New Hampshire Department of Environmental Services; USGS, U.S. Geological Survey]

\begin{tabular}{lcl}
\hline \multicolumn{1}{c}{ NHDES well identifier } & Sample collection date & USGS station (site) name \\
\hline OKT_DW-25 & $8 / 30 / 2011$ & NH-MOW 445 \\
OKT_DW-24 & $8 / 30 / 2011$ & NH-MOW 446 \\
OKT_DW-5A & $8 / 30 / 2011$ & NH-MOW 439 \\
OKT_DW-2 & $8 / 30 / 2011$ & NH-MOW 440 \\
OKT_DW-9A & $8 / 30 / 2011$ & NH-MOW 441 \\
OKT_DW-12 & $8 / 30 / 2011$ & NH-MOW 442 \\
OKT_DW-6 & $8 / 30 / 2011$ & NH-MOW 447 \\
OKT_DW-17 & $8 / 30 / 2011$ & NH-MOW 448 \\
OKT_DW-29 & $8 / 31 / 2011$ & NH-MOW 449 \\
OKT_BR-4 & $9 / 01 / 2011$ & NH-MOW 438 \\
OKT_BR-3 & $9 / 01 / 2011$ & NH-MOW 437 \\
OKT_MW-30 & $9 / 01 / 2011$ & NH-MOW 436 \\
\hline
\end{tabular}


Prepared by the Pembroke Publishing Service Center.

For more information concerning this report, contact:

Office Chief

U.S. Geological Survey

New England Water Science Center

New Hampshire-Vermont Office

331 Commerce Way, Suite 2

Pembroke, NH 03275

dc_nh@usgs.gov

or visit our Web site at:

http://nh.water.usgs.gov 
